\title{
WHAT DRIVES MERGERS \& ACQUISITIONS WAVES OF LISTED COMPANIES OF THE CHINEXT MARKET? IPO OVER-FINANCING OR STOCK OVERVALUATION
}

\author{
Xin $\mathrm{XU}^{1 \star}$, Yong-jin LIANG ${ }^{2}$, Shun-lin SONG \\ ${ }^{1,2}$ Zhongnan University of Economics and Law, School of Accounting, Wuhan, China \\ ${ }^{3}$ Central University of Finance and Economics, School of Accountancy, Beijing, China
}

Received 24 August 2017; accepted 24 March 2018

\begin{abstract}
A wave of mergers and acquisitions (M\&A) has been consistently rising among the China's ChiNext companies over the past years, which has drawn great attention across academia and industry. Based on the neoclassical theory and the behavioral theory, this paper explores the driving factors of M\&A among Chinese ChiNext companies. Two hypotheses were put forward: one based on IPO over-financing and the other based on the market value overvaluation. IPO over-financing is specific to the Chinese capital market while market value overestimation is driven by the continuous upsurge in the ChiNext Market. Our study found that both factors account for enterprises' mergers and acquisitions. They have far-reaching influences on such fields as acquisition probability, the size of the transaction, transaction frequency, M\&A payment method and market reaction. Due to IPO over-financing, enterprises tend to carry out M\&A via cash payment or cash and stock mixed payment method. Heavier IPO over-financing will increase the chance of M\&A and leads to larger transaction size and higher transaction frequency. Market value overvaluation will lead to more uses of stock or cash and stock mixed payment on M\&A transactions. When the company's stock is overvalued, the company will use the overvalued equity to acquire other companies. Greater overvaluation of the market value also increases the chance of M\&A and leads to a larger transaction size and higher frequency of M\&A. In China, IPO over-financing rather than market value overvaluation, is the major driving factor for China's corporate mergers and acquisitions. Further study found that the market reaction to different payment methods in mergers and acquisitions varies: it has the minimum reaction on cash payment, a larger reaction on stock payment and the greatest reaction on mixed payment. Also, the mixed payment method has the largest cumulative abnormal returns. This is different from the empirical findings in the United States and Europe. This paper provides a theoretical basis and empirical evidence for an in-depth understanding of the wave of mergers and acquisitions of Chinese ChiNext companies, and provides a basis for decision-making and policy recommendations for the government regulators and investors.
\end{abstract}

Keywords: The ChiNext Market, M\&A, IPO over-financing, stock overvaluation, method of payment.

JEL Classification: G10, G34.

${ }^{\star}$ Corresponding author. E-mail: xuxinfeiji@126.com

This is an Open Access article distributed under the terms of the Creative Commons Attribution License (http://creativecommons. org/licenses/by/4.0/), which permits unrestricted use, distribution, and reproduction in any medium, provided the original author and source are credited. 


\section{Introduction}

China has been constantly increasing its financial support for independent innovation in order to construct an innovative country. The ChiNext market is a momentous institution created to accelerate the implementation of an independent innovative country and promote the combination of technology and finance. With rapid developments in recent years, the ChiNext market has now become the new engine of China's innovation economy. It provides huge amounts of capital for the cultivation and development of strategic emerging industries and the optimization and upgrading of China's industrial structures. However, among, the "Three highs and one abnormal", i.e. high IPO over-financing, high P/E ratios, high stock prices and abnormal fluctuations have frequently happened in the market and have aroused wide and great concern among domestic media, governmental departments and scholars: it appears to be hazards to the healthy development of the ChiNext market.

The ChiNext market has seen a wave of M\&A in the recent years. There's a significant tendency of growth in the frequency and size of M\&A. More and more companies are involved in M\&A transactions as well. Both the frequency and size of M\&A and the companies involved in M\&A transactions are far greater than small and medium Enterprise board (SME) and the main board stock market in the same period. Relevant statistical data reveals that 431 out of 570 ChiNext companies have carried out 2206 M\&A transactions, the size of which adds up to $¥ 439.6$ billion as of the end of 2016. In the single year of 2015 there are 301 out of 492 ChiNext companies conducting 724 times of M\&As. Besides, many companies have experienced high-frequency serial M\&A, and the number continues to go up. 104 and 178 companies have been involved in more than one M\&A transaction in the year of 2014 and 2015 respectively. Bluefocus Communication Group Co., Ltd. (300058), being acclaimed as the NO.1 stock of public relations by the media, conducted 31 M\&A transactions just in the year of 2014, which becomes a typical case. This makes Bluefocus the company with most frequent M\&A transactions since the foundation of the stock market in China. There are plenty of Bluefocus in the ChiNext market, revealing the madness of the wave of M\&A.

Compared to the SME and the main board stock market, ChiNext companies have stronger motivation to carry out M\&As. The main reason lies in that Interim Measures on Administration of Initial Public Offering and Listing on the ChiNext promulgated by China Securities Regulatory Commission on March 31st, 2009 and Measures on Administration of Initial Public Offering and Listing on the ChiNext on May 14th, 2014 explicitly state that "Issuers in the ChiNext market shall mainly engage in one main business". Accordingly, emphases on business simplification exclude the possibilities of diversification, which turns into a catalyst for M\&A so as to achieve a sharp expansion after company's IPO.

Fund supporting is crucial to completion of M\&A in addition to the motiation (Faccio \& Masulis, 2005; Harford, 2005; Eckbo, 2009; Hu \& Yang, 2016; Tao, Sun, Zhu, \& Zhang, 2017). IPO over-financing and market overvaluation foster the expansion of ChiNext companies. IPO over-financing is characteristic of the Chinese capital market and is particularly obvious in the ChiNext market. IPO over-financing exists in 62.6\% of ChiNext companies, 357 out of 570 ChiNext companies as of December 31, 2016. The actual net funds raised added up to $¥ 277.798$ billion while the expected amount raised via IPO was $¥ 158.204$ billion, indicating 
an over-financing scale of $¥ 119.594$ billion. Unlike IPO raised capital that must be used for specified purposes committed in prospectuses, IPO over-financing is not bound by any such commitment and can be used at the company's discretion. According to related provisions by the China Securities Regulatory Commission, it is free to change the intended investment areas of IPO over-financing. There is no commitment related to an established purpose and investment plan for funds raised in excess of the IPO target, and no problem would arise even if the investments for which such funds were used changed. Excess funds raised in an IPO are essentially an extra portion of capital given to the company by its shareholders when the company goes public, and is akin to manna from heaven (Xu \& Xia, 2012).

In response to the indiscriminate waste of IPO over-financing, Memorandum No.1 on Information Disclosure by ChiNext Companies - IPO Over-financing, which is hereinafter referred to as the memorandum, is revised in August, 2012 by the Shenzhen Stock Exchange. The memorandum aims at improving the security of financing and the efficiency of the use of funds, standardizing the management and use of IPO over-financing funds. Strict restrictions have been made about utilizing the funds, including that those funds shall be used for company's major business and shall not be used for security investment, commissioned financial management, derivatives investment, venture capital, other high-risk investment or financial support for others. IPO over-financing funds that are used for permanently supplementing working capital or repaying bank loans should accumulate to no more than $20 \%$ of the total IPO over-financing funds in every 12 months. IPO over-financing funds that are applied to temporarily supplementing working capital will be regarded as the same as idle raising funds. However, the memorandum doesn't restrict IPO over-financing funds for M\&A. Given the restrictions imposed on over-financing and the weak endogenous growth of ChiNext companies, M\&A has become a major field of application of raised funds.

In addition, most ChiNext companies are regarded as the leading enterprises in high-tech and high-growth industry. They are generally favored and sought after by an overwhelming majority of investors for they represent the hope of China's innovative economy. Market value overestimation is widespread and the P/E just can't go down, even if it's over a hundred times. The total market value of the ChiNext market in 2015 was $¥ 5591.625$ billion, while in 2009 it’s only $¥ 161.008$ billion. The same thing happens in the ChiNext market Index, which was 1137.66 in 2010 and 2714.05 in 2015. In this context, making use of market value overestimation for stock-exchange M\&A becomes an effective approach to market value management for ChiNext companies. As indicated in the research paper of China Merchants Securities, the stock price generally goes up sharply right before a company carries out M\&A, and the average rolling $\mathrm{P} / \mathrm{E}$ ratio even climbs up to 194 . All in all, taking advantage of market value overestimation to purchase underestimated physical assets of non-listed companies has gotten to be a gold key to capital operation and rapid expansion of ChiNext companies.

It can be seen that ChiNext companies have been the pioneer in M\&A activities for their strong motives and expansion power. The study of the acquisition probability, transaction frequency, transaction size, targeted company, payment method, economic consequences and causes of M\&A in the ChiNext market is urgent and thus is contributive to constructing the specific M\&A theory for China under this circumstance. 
Moreover, abundant cash flow owing to IPO over-financing and market overvaluation simultaneously exist in most ChiNext companies, is a phenomenon rarely seen in other countries. According to the neoclassical theory, M\&A via cash payment rather than stock payment tends to be more common when the capital market liquidity is strong (Harford, 1999, 2005). The behavioral theory believes that abundant cash flow and market overvaluation won't exist in one place at the same time, and that evaluation itself can be the single primary drive for M\&A regardless of the motives (Shleifer \& Vishny, 2003; Rhodes-Kropf \& Viswanathan, 2004; Rhodes-Kropf, Viswanathan, \& Robinson, 2005). It also suggested that overestimated stock will dominate M\&A and thus alleviate weak capital market liquidity when companies are short of cash. Existing M\&A theories cannot fully explain the special phenomenon in China stock market. Therefore, study of how ChiNext enterprises optimize the best payment methods in the unique situation will provide a valuable information to examine existing M\&A theories and construct the M\&A theories for China.

M\&A activity is an important way for capital market to play the function of resource allocation. Study of M\&A in the ChiNext market is of both theoretical and practical significance for the optimization of the allocation of resources, the advance of industrial transformation and upgrade as well as the development of national innovative economy. The main focus of this paper is to offer clear insights into the origins and drives of the M\&A upsurge in the ChiNext market since there's a lack of related study in current literature.

Based on the neoclassical theory and the behavioral theory and the unique phenomena in the ChiNext market, this paper proposes IPO over-financing hypothesis and the market overvaluation hypothesis to account for the M\&A upsurge in this market. The marginal contributions of this paper are as follows.

Firstly, this paper describes the M\&A characteristics in the special environment of the ChiNext market and provides an interpretation of the M\&A upsurge. It has been found out that IPO over-financing, which is specific to the Chinese capital market, and market value overestimation, which is driven by the continuous upsurge in the ChiNext Market, cause enterprises' mergers and acquisitions. Both bring far-reaching impact on acquisition probability, transaction size, transaction frequency, M\&A payment method, target companies and market reaction. Rather than market value overvaluation, IPO over-financing is the major driving factor for China's corporate mergers and acquisitions. This paper provides a theoretical basis and empirical evidence for our in-depth understanding of the wave of M\&A of Chinese ChiNext companies, and is good supplement to existing theories of M\&A.

Secondly, given there is very limited research on the Chinese capital market reaction to payment methods, this paper studied it in detail. Our study found that, the market reaction to different payment methods in M\&A varies: it has a minimum reaction on cash payment, a larger reaction on stock payment and the largest reaction on mixed payment. Also, the mixed payment method has the largest cumulative abnormal returns. This is different from the empirical findings in the United States and Europe. These findings provide a theoretical basis and empirical evidence that will enable us to understand in-depth the market reaction and the payment method of M\&A and help ChiNext companies and investors make rational investment decisions in the meantime.

Thirdly, this paper deepens the understanding of how IPO over-financing and market value overvaluation affect the microeconomic behavior of enterprises from the perspective 
of the wave of M\&A, especially our understanding of how IPO over-financing results in resources mismatches. This provides a basis for decision-making and policy recommendations in optimization of resource allocation of capital markets and promotion of the healthy development of the ChiNext market for the government regulators and investors.

The remainder of this paper is organized as follows. Section 1 reports our theoretical analysis and research hypotheses. Section 2 describes the research design. Section 3 documents the empirical results and analysis. Section 4 discusses the market reaction to payment methods. Finally, last section draws a conclusion.

\section{Theoretical analysis and research hypotheses}

\subsection{Theoretical analysis and literature review}

In the theory of the wave of M\&A there are two main schools of thoughts: the neoclassical theory is based on the premise of efficient market; the behavioral theory is based on the premise of non-efficient market. Neoclassical theory claims that M\&A is the reconfiguration of resources whose aim is to improve efficiency in response to the external environmental changes including technological changes and innovation, industry-specific deregulations, economic shocks and so on (Mitchell \& Mulherin, 1996; Maksimovic \& Phillips, 2001). It also pointed out that M\&A is a manifestation of the profit-pursuing nature of capital, as capital flow prefers high-quality and efficient enterprises to low-quality and inefficient ones (Servaes, 1991; Jovanovic \& Rousseau, 2002; Harford, 2005). Additionally, the neoclassical theory supports the idea that capital liquidity is the fundamental driving force behind M\&A. Neoclassical theory can only forecast the wave of M\&A when the capital liquidity is strong. To be specific, stronger capital liquidity leads to more M\&A via cash payment and decreases in capital liquidity will impede the wave of M\&A (Harford, 2005). Enterprises' microeconomic data collected in Harford (1999)'s research corroborated the above findings, which implies that companies with abundant cash flows are more likely to be bidders than targets as they have stronger liquidity. Abundant cash flows enable companies to mitigate financing constraints and conduct M\&A.

Behavioral theory holds the view that stock market's misvaluation and senior executives' opportunistic behavior account for the wave of M\&A (Shleifer \& Vishny, 2003; Rhodes-Kropf \& Viswanathan, 2004; Rhodes-Kropf et al., 2005; Savor \& Lu, 2009). Although Shleifer and Vishny (1992) also acknowledgeed the important impacts of capital liquidity on resources reconfiguration and that increased cash flow in a prosperous stock market enhances the basic value of assets and mitigates the financing constraints, resulting in stock prices close to their true values and the wave of M\&A.

Each coin has two sides. On the one hand, abundant cash flows, being strategically significant, are helpful to mitigate the friction of capital markets and meet the demands of investment (Harford, 1999; Officer, 2007). On the other hand, abundant cash flows aggravate the agency problems between shareholders and managers (Jensen, 1986). According to the agency theory, due to the separation of ownership and management in modern enterprises, management tends to act selfishly and deviates from the interests of shareholders: they will carry out such activities as company-paid consumption, blind M\&A, excessive investment 
and empire building of managers when there are abundant cash flows (Jensen, 1986). Jensen (1986) puts forward that, in the 1970s and 1980s, enterprises in American petroleum and tobacco industries damage the interests of investors through conducting blind M\&A instead of distributing cash dividends when there was production overcapacity. Since then a great sum of empirical researches support the free cash flow hypothesis of Jensen, arguing that scale of cash flows commanded by managers is closely related to the frequency of M\&A, which have an overall bad influence on firm values (Lang, Stulz, \& Walking, 1991; Harford, 1999).

\subsection{Institutional analysis and the IPO over-financing hypothesis}

IPO over-financing is a long-term phenomenon unique to the Chinese capital market. It has been existing since 1991 when the capital market was first established. IPO over-financing happens in considerable newly listed companies every year. The frequency and scale of IPO over-financing has been growing rapidly since 2009 and is typical and prominent in the ChiNext market.

All accounting and financial behaviors are rooted in specific institutional environments (Liu, 2017). We believe that IPO over-financing is essentially a reflection of the excess liquidity in Chinese stock market. The four-trillion economic stimulus plan after the 2008 financial crisis, domestic private capital that pursues high returns but with limited investment channels and speculative international capital, all together led to the capital redundancy in the stock market, which further contributed to IPO over-financing. Although Guiding Opinions on Further Reforming and Improving the Issuance System of New Shares promulgated by CSRC on June 10th, 2009 and Guiding Opinions on Deepening the Reforms in the Issuance System of New Shares on October 11th, 2010 have been working on the issuance system of new shares and focusing on the key points of pricing and issuing, this cannot fully eliminate IPO overfinancing in terms of the sources of capital liquidity redundancy (Song, Tan, \& Yi, 2014).

IPO over-financing reflects the irrationality and imperfection of the stock market and brings about resource allocation mismatches and low capital utilization efficiency. Capital over-allocation to a small number of companies causes low efficiency of resource allocation: excessive financing of one company means the increased financing difficulties of other companies desperate for money at the same time (J. X. Fang \& F. Fang, 2011; Xu \& Xia, 2012). As for those companies who are experiencing IPO over-financing, excessive and indiscriminate investments are highly possible because of the agency conflicts. In the light of existing literature, IPO over-financing is closely correlated to serious violations of the interests of small and medium investors, such as excessive executive compensation, indiscriminate investment and tunnel effects (J. X. Fang \& F. Fang, 2011; Xu \& Xia, 2012).

Jensen (1986) proposes the famous free cash flow hypothesis, which defines free cash flow as cash flow left after the firm has invested in all available positive NPV projects, claiming that free cash flow cultivates severe agency conflicts. We think that IPO over-financing is essentially the referred free cash flow at the microeconomic level. However, compared to free cash flow, IPO over-financing results in worse agency conflicts, because stock change less rapidly than flows (Shleifer \& Vishny, 1992). IPO over-financing belongs to stock funds, which changes slower than free cash flows and results in lasting agency conflicts. 
In response to the indiscriminate waste of IPO over-financing, Memorandum No.1 on Information Disclosure by ChiNext Companies - IPO Over-financing, which is hereinafter referred to as the memorandum, is revised in August, 2012 by Shenzhen Stock Exchange. The memorandum targets at improving the security of financing and the efficiency of the use of funds, standardizing the management and use of IPO over-financing funds. Strict restrictions have been made about utilizing the funds, including that those funds shall be used for company's major business and shall not be used for security investment, commissioned financial management, derivatives investment, venture capital, other high-risk investment or financial support for others. IPO over-financing funds that are used for permanently supplementing working capital or repaying bank loans should accumulate to no more than $20 \%$ of the total IPO over-financing funds in every 12 months. IPO over-financing funds that are applied to temporarily supplementing working capital will be regarded as the same as idle raising funds. However, the memorandum doesn't restrict IPO over-financing funds for M\&A. ChiNext companies are generally high-growth firms. M\&A contributes to companies' extensive development, which logically becomes the first choice of most ChiNext companies when internal development is limited. Therefore, considering the weak internal development power, strong motives and abilities as well as the rigid regulation power, huge IPO over-financing funds have been applied for M\&A.

Based on the neoclassical theory, the behavioral theory and the background of ChiNext market, we have deduced the IPO over-financing hypothesis. As a reflection of the excess liquidity in Chinese stock market, IPO over-financing is essentially the ample free cash flow endowed by investors. IPO over-financing drives the enterprise to conduct M\&A and brings far-reaching impact on acquisition probability, the size of the transaction, transaction frequency, method of payment and market reaction. Method of payment, including stock, cash, cash and stock mixed payment, are crucial to a suitor for their successful completion of the M\&A, and thus become an important topic in M\&A literature (Faccio \& Masulis, 2005; Xu, 2017). The source of financing largely determines the payment method of M\&A. Faccio and Masulis (2005) have pointed out that the amount of cash held by the company and the ability to take on debt are the primary factors of the payment method. Consequently payment methods are considered as synonyms of the source of financing in the related literature (Martynova \& Renneboog, 2009). The financing cost of IPO over-financing funds is nearly zero, since they are the extra capital acquired by equity financing. Thus IPO over-financing make ChiNext companies prefer cash payment of M\&A to other payment methods. A clear understanding has been formed of the characteristics, causes and economic consequences of M\&A payment methods in China through our study. To sum up, we propose the IPO overfinancing hypothesis as follows:

Hypothesis 1: If other conditions remain unchanged, IPO over-financing will drive the enterprises to conduct MঊA. Heavier IPO over-financing leads to higher chance of MঊA, larger transaction size, higher transaction frequency and more uses of cash payment on MઐA transactions. 


\subsection{Irrationality of the ChiNext market and the market overvaluation hypothesis}

Maksimovic and Phillips (2001) and Jovanovic and Rousseau (2002) have noted the phenomenon of enterprises using over-valued stock for M\&A. The wave of M\&A relates to the upsurge of the capital market. Besides, enterprises prefer stock payment when stock market is enjoying a boom (Andrade, Mitchell, \& Stafford, 2001; Holmstrom \& Kaplan, 2001; Baker, Stein, \& Wurgler, 2003), resulting in the domination of stock payment in M\&A activities (Rhodes-Kropf \& Viswanathan, 2004; Savor \& Lu, 2009). Compared to companies who use cash payment in M\&A, those companies who choose stock payment have higher M/B (Maksimovic, Phillips, \& Yang, 2013).

Scholars such as Shleifer and Vishny (2003) and Rhodes-Kropf and Viswanathan (2004) point out that although the neoclassical theory offers a good rationale of M\&A to a large extent, the theory is not complete when it comes to the selection of payment methods, such as how bidders make a decision between cash payment and stock payment and why the economic consequences of M\&A aren't always positive. To answer these questions, Shleifer and Vishny (2003) bring about a theory stating that market value overvaluation is the driving force behind M\&A. They deem the market inefficient resulting in the inaccuracy of the evaluation of enterprises. Executives are thought to be fully rational and they know exactly whether a company is overestimated or not. Therefore, they can take advantage of the inefficiency of the market select right timing for M\&A and arbitrage. Overestimated companies tend to use equity financing for physical assets in M\&A in order to avoid the loss in case the stock price goes down. Empirical evidence from Ang and Cheng (2006) supported above claim: it shows that overestimated companies do prefer stock payment in M\&A due to executives' opportunistic behavior. Bekkum, Han, and Pennings (2011) also supports the idea that M\&A helps companies to cope with variations of stock prices.

Rhodes-Kropf and Viswanathan (2004) provided some further insights. They stateed that the misvaluation caused by the information asymmetry between bidders and targets accounts for the wave of M\&A. The information asymmetry affects the characteristics, status and payment method of M\&A. High misvaluation makes the target management accept more bids from overvalued bidders during market valuation peaks because they overestimate synergies during these periods. Besides, Rhodes-Kropf and Viswanathan (2004) further pointed out that valuation itself can be the fundamental driving force for M\&A regardless of the motives, while technological innovation, governmental deregulation and economic shocks referred to by the neoclassical theory are not necessary conditions. Empirical evidence from RhodesKropf et al. (2005) corroborated the idea. They creatively divide M/B into three parts: the short-term mispricing derived from the company's characteristics, the long-term mispricing at the industry level and the difference between the internal value and book value of the company (ie, future growth opportunities). The targets tend to accept the M\&A using overvalued stocks since the targets cannot distinguish these three misvaluation. Further study found out that companies with lower future growth opportunities tend to acquire companies with higher future growth opportunities. Dong, Hirshleifer, Richardson, and Hong Teoh (2006) and Tebourbi (2012)'s research came to the same conclusion.

The ChiNext market now becomes the new engine of China's innovation economy in the era of mass entrepreneurship and innovation. Most ChiNext companies are regarded 
as the leading enterprises in high-tech and high-growth industry. They commonly enjoy a groundswell of enthusiasm of investors, for they stand for the hope of China's innovative economy. Market value overestimation is widespread and the P/E just can't go down, even if it’s over a hundred times. The total market value of the ChiNext market in 2015 is $¥ 5591.625$ billion, while in 2009 it’s only $¥ 161.008$ billion. The same thing happens to the ChiNext market Index, which is 1137.66 in 2010 and 2714.05 in 2015. Moreover, the cumulative yearly turnover also increased from ¥182.811 billion in 2009 to $¥ 28535.281$ billion in 2015 , as summarized in Table 1. It can be seen that hypotheses of the behavioral theory apply to the practice in the ChiNext market, i.e. stock prices are far higher than their true value.

Table 1. Basic information of the ChiNext market from 2009 to 2016

\begin{tabular}{|l|c|c|c|c|c|c|c|c|}
\hline \multicolumn{1}{|c|}{ Item } & 2009 & 2010 & 2011 & 2012 & 2013 & 2014 & 2015 & 2016 \\
\hline $\begin{array}{l}\text { Number } \\
\text { of listed } \\
\text { companies }\end{array}$ & 36 & 153 & 281 & 355 & 355 & 406 & 492 & 570 \\
\hline $\begin{array}{l}\text { Total market } \\
\text { value } \\
\text { (100 million) }\end{array}$ & 1610.08 & 7365 & 7433.79 & 8731.2 & 15091.98 & 21850.95 & 55916.25 & 52254.5 \\
\hline $\begin{array}{l}\text { The ChiNext } \\
\text { Index P }\end{array}$ & - & 1137.66 & 729.5 & 713.86 & 1304.44 & 1471.76 & 2714.05 & 1962.05 \\
\hline $\begin{array}{l}\text { Weighted } \\
\text { average stock } \\
\text { price (yuan } \\
\text { per share) }\end{array}$ & 46.53 & 42.07 & 18.61 & 14.53 & 19.82 & 20.28 & 30.38 & 19.86 \\
\hline \begin{tabular}{l} 
Average P/E \\
\hline $\begin{array}{l}\text { Accumulated } \\
\text { yearly turnover } \\
\text { (100 million) }\end{array}$
\end{tabular} & 1828.11 & 15718 & 18879.12 & 23304.63 & 51181.94 & 78041.35 & 285352.81 & 216831.62 \\
\hline
\end{tabular}

Source: Shenzhen Stock Exchange Website (www.szse.cn).

Jensen (2005) argued that managers should not let stock prices get too high. When a firm's equity becomes substantially overvalued it sets in motion a set of organizational forces that extremely difficult to manage, forces that almost inevitably lead to destruction of part or all of the core value of the firm (Jensen, 2005). Failure of market for corporate control and severe agency conflicts may be caused by high stock prices. Stock prices being too high will likely to end up with the damage to firm value, stock price crash and loss of investors. Excessive stock prices will also result in the overdraft of future room for growth, too much earnings management and financial frauds. Therefore, it's an effective and wise choice for listed companies to manage market value by taking advantage of market value overestimation to purchase underestimated physical assets. A classical case is the acquisition of the Time Warner by the America Online in stock payment before the American technology stock bubble burst in 2000. It was considered a bad decision then, but now everyone thinks it's pretty wise. The America Online was a typical technology stock and had been overvalued for a long time. Through the acquisition of physical assets of the Time Warner, which belonged 
to traditional industries, its stock price got backed up. Similar acquisition strategy is universally used by contemporary American high-tech and high-flying companies (Rhodes-Kropf \& Viswanathan, 2004). Recently it has been found out that overvalued companies can create long-term value for the shareholders through M\&A (Savor \& Lu, 2009; Arikan \& Stulz, 2016). Overvalued companies who don't successfully carry out M\&A perform worse in the long run than those companies who do. We can draw the conclusion that in the long-term shareholders will benefit from right timing M\&A by the companies. Taking realistic practice in China into consideration, making use of overvalued stock under the continuous upsurge in the ChiNext Market to carry out M\&A contributes to managing market value and realizing external development.

Behavioral Theory offers the explanation as to why overvalued companies utilize the stock payment method. However, not every overvalued company acts in the same way, so we still lack systematic evidence to prove that high stock prices determine the payment method of M\&A (Eckbo, 2009), especially in the ChiNext market (Betton, Eckbo, \& Thorburn, 2008). Whether the behavioral theory is suitable to interpret the exact reality of China remains to be further verified, especially for the ChiNext market. The specialty about the ChiNext market lies in three aspects. Firstly, as an important part of capital liquidity, high market value can effectively alleviate the financing constraints. Yet in this market IPO over-financing exists simultaneously, which will also affect the choice of payment methods: it may reduce the inevitability of stock payment. Secondly, we found that all targets of M\&A in the ChiNext market are non-listed companies, which is the opposite of the cases in the American and Europe (Harford, 2005; Faccio \& Masulis, 2005; Moeller, Schlingemann, \& Stulz, 2005; Betton et al., 2008; Maksimovic et al., 2013). Non-listed companies are often undervalued due to the lack of liquidity, which also results in a discount in M\&A (Officer, 2007). Stock payment is welcome because the stock of listed companies is of high liquidity (Chang, 1998; Faccio \& Masulis, 2005). Thirdly, in conformity with Circular on Some Policy Questions Concerning the Handling of Income Taxes in the Restructuring of Enterprises ([2009] No. 59) promulgated by Ministry of Finance of the People's Republic of China and State Administration of Taxation, companies involved in stock-exchange acquisitions enjoy special tax treatment and taxsaving effect. When stock payment makes up no less than $85 \%$ of the total amount of the transaction, the stock payment shall not be subject to the enterprise income tax. Therefore, target companies are willing to accept the stock payment and a discount of the price paid by suitors due to the reduction of corporate income tax. Given all above factors, whether ChiNext companies experiencing market value overvaluation should carry out M\&A with stock payment is a problem waiting for an answer. To summarize, we propose the market overvaluation hypothesis as follows:

Hypothesis 2: If other conditions remain unchanged, market value overvaluation will drive the enterprises to conduct MઐA. Greater overvaluation of the market value leads to higher chance of $M \mho A$, larger transaction size, higher transaction frequency and more uses of stock payment on M\&A transactions. 


\subsection{The market reaction to payment methods}

Study of the wealth effect of different method of payment has been an important issue in M\&A research (Andrade et al., 2001; Betton et al., 2008; Eckbo, 2009). The impact on shareholders' wealth varies as method of payment changes. According to the free cash flow theory put forward by Jensen (1986), cash payments can alleviate agency conflicts caused by free cash flows and prevent managers from gaining private interests through controlling free cash flows, thus creating more value for shareholders. For this reason, cash payments have a wealth effect. Stock payment often means lower abnormal returns for the shareholders of acquirers. It has been pointed out by Andrade et al. (2001) that stock acquisitions comprise the acquisition and issuance of stock at the same time. The company tends to choose stock payment when the market value is overvalued, otherwise cash payment will be the choice. Therefore, stock payments generally convey a negative signal to the market, resulting in significant lower abnormal returns than that of cash payments for the shareholders of suitors.

Literally the market reaction to stock payments is worse than that to cash payments. However, the empirical results showed the opposite. The reason for this is that stock acquisitions include not only the issuance of stock, but also the acquisition. Table 2 summarizes the relevant typical literature in recent years.

Table 2. Typical relevant empirical literature on the market reaction of bidders to payment methods

\begin{tabular}{|c|c|c|c|}
\hline Author & Research sample & Target type & Main conclusions \\
\hline $\begin{array}{l}\text { Servaes } \\
(1991)\end{array}$ & $\begin{array}{l}704 \text { times of M\&A } \\
\text { happened in } 384 \\
\text { American listed } \\
\text { companies from } 1972 \\
\text { to } 1987\end{array}$ & \begin{tabular}{|l|} 
Listed \\
companies
\end{tabular} & $\begin{array}{l}\text { Market reaction to cash payments is } \\
\text { significantly positive; } \\
\text { Market reaction to stock payments is } \\
\text { significantly negative; } \\
\text { Market reaction to cash and stock mixed } \\
\text { payments is significantly negative }\end{array}$ \\
\hline $\begin{array}{l}\text { Chang } \\
(1998)\end{array}$ & $\begin{array}{l}281 \text { acquisitions of } \\
\text { non-listed companies } \\
\text { happened from } 1981 \\
\text { to } 1992 \text { and } 255 \\
\text { acquisitions of listed } \\
\text { companies happened } \\
\text { from } 1981 \text { to } 1988 \\
\text { in American listed } \\
\text { companies }\end{array}$ & $\begin{array}{l}\text { Listed } \\
\text { companies } \\
\text { and non-listed } \\
\text { companies }\end{array}$ & $\begin{array}{l}\text { Characteristics of target companies have } \\
\text { profound influences on market reaction; } \\
\text { The CAR }(-1,0) \text { is significantly negative } \\
\text { for M\&A targeting at listed companies with } \\
\text { stock payments; } \\
\text { The CAR }(-1,0) \text { is significantly positive } \\
\text { for M\&A targeting at non-listed companies } \\
\text { with stock payments }\end{array}$ \\
\hline $\begin{array}{l}\text { Eckbo and } \\
\text { Thorburn } \\
\text { (2000) }\end{array}$ & $\begin{array}{l}416 \text { times of M\&A } \\
\text { happened in TSE listed } \\
\text { companies from } 1964 \\
\text { to } 1983\end{array}$ & $\begin{array}{l}\text { Listed } \\
\text { companies } \\
\text { and non-listed } \\
\text { companies }\end{array}$ & $\begin{array}{l}\text { The AAR (average abnormal return) is } \\
\text { significantly positive for M\&A with cash } \\
\text { payments in the announcement month; } \\
\text { The AAR (average abnormal return) is } \\
\text { significantly positive for M\&A with stock } \\
\text { payments in the announcement month; } \\
\text { The AAR (average abnormal return) } \\
\text { is significantly positive for M\&A with } \\
\text { cash and stock mixed payments in the } \\
\text { announcement month }\end{array}$ \\
\hline
\end{tabular}


End of Table 2

\begin{tabular}{|c|c|c|c|}
\hline Author & Research sample & Target type & Main conclusions \\
\hline $\begin{array}{l}\text { Andrade } \\
\text { et al. } \\
(2001)\end{array}$ & $\begin{array}{l}3688 \text { acquisitions } \\
\text { happened from } 1973 \text { to } \\
1998 \text { in American listed } \\
\text { companies }\end{array}$ & $\begin{array}{l}\text { Listed } \\
\text { companies } \\
\text { and non-listed } \\
\text { companies }\end{array}$ & $\begin{array}{l}\text { Market reaction to cash payments is better } \\
\text { than that to stock payments; } \\
\text { The CAR }(-1,1) \text { is significantly negative } \\
\text { for M\&A with stock payments; } \\
\text { The CAR }(-1,1) \text { is positive for M\&A } \\
\text { with cash payments, yet not statistically } \\
\text { significant }\end{array}$ \\
\hline $\begin{array}{l}\text { Datta, } \\
\text { Iskandar- } \\
\text { Datta and } \\
\text { Raman } \\
(2001)\end{array}$ & $\begin{array}{l}1719 \text { acquisitions } \\
\text { happened from } 1993 \text { to } \\
1998 \text { in American listed } \\
\text { companies }\end{array}$ & $\begin{array}{l}\text { Listed } \\
\text { companies }\end{array}$ & $\begin{array}{l}\text { Market reaction varies with payment } \\
\text { methods; } \\
\text { The CAR }(-1,0) \text { is significantly positive for } \\
\text { M\&A with cash payments; } \\
\text { The CAR }(-1,0) \text { is significantly negative } \\
\text { for M\&A with non-cash payments }\end{array}$ \\
\hline $\begin{array}{l}\text { Fuller, } \\
\text { Netter, and } \\
\text { Stegemoller } \\
(2002)\end{array}$ & $\begin{array}{l}3135 \text { acquisitions } \\
\text { happened in } 539 \text { listed } \\
\text { companies in NYSE, } \\
\text { Nasdaq and AMEX } \\
\text { from } 1990 \text { to } 2000 ; \\
\text { each company has to } \\
\text { be involved in at least } 5 \\
\text { M\&A transactions }\end{array}$ & $\begin{array}{l}\text { Listed } \\
\text { companies, } \\
\text { affiliates } \\
\text { of listed } \\
\text { companies } \\
\text { and non-listed } \\
\text { companies }\end{array}$ & $\begin{array}{l}\text { M\&A targeting at non-listed companies } \\
\text { results in gains of shareholders, while M\&A } \\
\text { targeting at listed companies ends up with } \\
\text { losses; } \\
\text { For M\&A targeting at non-listed } \\
\text { companies, the CAR }(-2,2) \text { is significantly } \\
\text { positive for cash payments, stock payments } \\
\text { as well as cash and stock mixed payments. } \\
\text { The market reaction has a minimal reaction } \\
\text { on cash payment, a larger reaction on stock } \\
\text { payment and a greatest reaction on mixed } \\
\text { payment; } \\
\text { For M\&A targeting at listed companies, the } \\
\text { CAR (-2, 2) is positive for cash payments } \\
\text { as well as cash and stock mixed payments, } \\
\text { yet not significant. The CAR (-2, } 2 \text { ) is } \\
\text { significantly negative for stock payments }\end{array}$ \\
\hline $\begin{array}{l}\text { Moeller } \\
\text { et al. } \\
(2004)\end{array}$ & $\begin{array}{l}12023 \text { acquisitions } \\
\text { happened from } 1980 \text { to } \\
2001 \text { in American listed } \\
\text { companies }\end{array}$ & $\begin{array}{l}\text { Listed } \\
\text { companies, } \\
\text { affiliates } \\
\text { of listed } \\
\text { companies } \\
\text { and non-listed } \\
\text { companies }\end{array}$ & $\begin{array}{l}\text { Market reaction varies violently with } \\
\text { payment methods and types of target } \\
\text { companies; } \\
\text { For M\&A targeting at non-listed } \\
\text { companies, the CAR }(-1,1) \text { is significantly } \\
\text { positive for cash payments, stock payments } \\
\text { as well as cash and stock mixed payments. } \\
\text { For M\&A targeting at listed companies, the } \\
\text { CAR }(-1,1) \text { is positive for cash payments, } \\
\text { yet not significant. The CAR }(-1,1) \text { is } \\
\text { significantly negative for stock payments as } \\
\text { well as cash and stock mixed payments }\end{array}$ \\
\hline
\end{tabular}

A consensus has been reached by scholars that the market reaction varies with payment methods as can be seen in Table 2. Yet empirical evidence contradicts one another in such issues as whether the differences of market reaction are significant, whether markets react better to cash payments than stock payments and whether markets react necessarily negatively to stock payments. Besides, we are short of empirical evidence from emerging capital markets. Researches of Chang (1998) and Fuller et al. (2002) made the conclusion that types of target companies have profound influences on market reaction. M\&A targeting at non- 
listed companies results in gains of shareholders, while M\&A targeting at listed companies ends up with losses. After that, empirical evidence from Moeller et al. (2004) reached a similar conclusion that types of target companies should be taken into consideration in the topic of the market reaction.

M\&A with cash payments is a sensible application of giant IPO over-financing funds in the ChiNext market, mitigating the agency conflicts caused by free cash flows. In this paper, we expect the market reaction to cash payments to be positive. At present, M\&A transactions in the ChiNext market are all targeting at non-listed companies, which are universally under valued due to the lack of liquidity. Suitors often enjoy a discount in acquisitions of physical assets of non-listed companies. In this background, making use of market value overestimation for M\&A becomes an effective approach of market value management for the ChiNext companies. In the long term the shareholders will benefit from M\&A in selective timings. We thus expect the market reaction to stock payments to be positive. To sum up, we propose the hypothesis as follows:

Hypothesis 3: If other conditions remain unchanged, the market reaction to cash payments and stock payments to be positive.

\section{Research design}

\subsection{Data sources and sample selection}

This paper takes companies listed on the ChiNext market from 2009 to 2016 as research samples. Relevant M\&A data come from the Wind database and the financial data are from the CSMAR database. We filter the sample following these rules: Firstly, to ensure the accuracy of the data we exclude those M\&As that are pure rumors, those not passed by the Issuance Examination Committee of China Securities Regulatory Commission or the shareholders'meeting and those that fail or are terminated during implementation. Secondly, we eliminate those M\&A samples which are substantially for the acquisition of land, property or cars. Thirdly, we remove the samples of non-fair transactions, such as the purchase of 30\% equity of Xiuqiang Optronic Co., Ltd. by Xiuqiang Glasswork Co., Ltd. (100160), the purchase of $45 \%$ equity of Hong Kong Liantronics Co., Ltd. by Shenzhen Liantronics Co., Ltd. (300269) and the purchase of $49 \%$ equity of Telande Technology Co., Ltd. by Shenzhen Riland Industry Co., Ltd. (300154). Finally, we skip those transactions that do not disclose the detailed amount of trade. This paper sets as the control group ChiNext companies that are not involved in any M\&A from 2009 to 2016. Eventually we got 3618 observation samples, corresponding to 2632 ChiNext companies, as summarized in Table 3.

\subsection{Model specification and variable definitions}

We examine the effects of IPO over-financing and market value overvaluation on enterprises' mergers and acquisitions from four aspects: acquisition probability, the size of the transaction, transaction frequency and M\&A payment methods. In this paper, the test models are constructed as follows. Based on previous related literature (Harford, 2005; Rhodes-Kropf et al., 2005; Ang \& Cheng, 2006; Dong et al., 2006; Savor \& Lu, 2009; Arikan \& Stulz, 2016), we construct the following Logit regression model (1) to (6) to investigate the effects of IPO 
over-financing and market value overvaluation on acquisition probability. Market to book value ratio $(\mathrm{MB})$, price to book value ratio $(\mathrm{Ppa})$ and Tobin's $\mathrm{Q}$ are used as proxies for market value overvaluation. There are no multi-collinearity problems. Table 4 presents the definitions of related variables.

$$
\begin{aligned}
& \operatorname{Logit}\left(M \& A_{-} \text {If }\right)=\beta_{0}+\beta_{1} I P O O F_{-} \text {If }+\beta_{2} M B+\beta_{3} \text { Lev }+\beta_{4} \text { Industry }+\beta_{5} \text { Year }+\zeta ; \\
& \operatorname{Logit}\left(M \& A \_ \text {If }\right)=\beta_{0}+\beta_{1} \text { IPOOF_If }+\beta_{2} P p a+\beta_{3} \text { Lev }+\beta_{4} \text { Industry }+\beta_{5} \text { Year }+\zeta \text {; } \\
& \operatorname{Logit}\left(M \& A_{-} \text {If }\right)=\beta_{0}+\beta_{1} \text { IPOOF_If }+\beta_{2} \text { Tobin's } Q+\beta_{3} \text { Lev }+\beta_{4} \text { Industry }+\beta_{5} \text { Year }+\zeta \text {; } \\
& \operatorname{Logit}\left(M \& A_{-} \text {If }\right)=\beta_{0}+\beta_{1} \text { IPOOF_Size }+\beta_{2} M B+\beta_{3} \text { Lev }+\beta_{4} \text { Industry }+\beta_{5} \text { Year }+\zeta \text {; } \\
& \operatorname{Logit}\left(M \& A_{-} \text {If }\right)=\beta_{0}+\beta_{1} \text { IPOOF_Size }+\beta_{2} P p a+\beta_{3} \text { Lev }+\beta_{4} \text { Industry }+\beta_{5} \text { Year }+\zeta \text {; } \\
& \operatorname{Logit}\left(M \& A \_I f\right)=\beta_{0}+\beta_{1} I P O O F \_ \text {Size }+\beta_{2} \text { Tobin's } Q+\beta_{3} \text { Lev }+\beta_{4} \text { Industry }+\beta_{5} \text { Year }+\zeta .(6)
\end{aligned}
$$

\begin{tabular}{|c|c|c|}
\hline Item & $\begin{array}{c}\text { Number of M\&A } \\
\text { transactions }\end{array}$ & $\begin{array}{l}\text { Companies-year } \\
\text { involved }\end{array}$ \\
\hline $\begin{array}{l}\text { M\&A transactions happened in the ChiNext market from } \\
2009 \text { to } 2016 \text { in the Wind database }\end{array}$ & 2379 & - \\
\hline $\begin{array}{l}\text { Subtract: M\&A which are either rumors or not passed by } \\
\text { the Issuance Committee or the shareholders' meeting and } \\
\text { the M\&A which stop or terminate in implementation }\end{array}$ & 145 & - \\
\hline the acquisition of land, property or cars & 44 & - \\
\hline non-fair transactions & 31 & - \\
\hline $\begin{array}{l}\text { transactions for increasing capital of subsidiaries but } \\
\text { declining the proportion of equity }\end{array}$ & 17 & - \\
\hline $\begin{array}{l}\text { transactions of ownership structure adjustment within } \\
\text { the group }\end{array}$ & 2 & - \\
\hline transactions that purchase of minority interests & 2 & - \\
\hline $\begin{array}{l}\text { transactions of delisting enterprises due to fraudulent } \\
\text { issuance }\end{array}$ & 2 & - \\
\hline $\begin{array}{l}\text { Add: transactions that missing due to an announcement } \\
\text { involving multiple transactions }\end{array}$ & 80 & - \\
\hline Subtract: repeated transactions & 10 & - \\
\hline Observation samples of M\&A & 2206 & 1135 \\
\hline $\begin{array}{l}\text { Add: Observation samples of control group } \\
\text { (Number of companies not involved in M\&A every year } \\
\text { from 2009-2016) }\end{array}$ & 1513 & 1513 \\
\hline $\begin{array}{l}\text { Subtract: transactions that do not disclose the detail trade } \\
\text { amount }\end{array}$ & 53 & $0^{\#}$ \\
\hline $\begin{array}{l}\text { transactions that missing financial data ( } 47 \text { samples } \\
\text { from M\&A transactions and } 1 \text { from control group) }\end{array}$ & 48 & 16 \\
\hline Observation samples of M\&A with financial data & 2106 & 1120 \\
\hline Total observation samples & 3618 & 2632 \\
\hline
\end{tabular}

Table 3. Sample selection

Note: \# indicates that although the detail amount data of M\&A are not disclosed, the calculation of the companies is not affected. So no data are omitted. 
The regression coefficient of IPOOF_If and IPOOF_Size, which are the proxies for IPO over-financing, are predicted significantly positive in the models. The regression coefficient of MB, Ppa and Tobin's Q, which are the proxies for market value overvaluation, are also predicted significantly positive in the models. The marginal effect of IPO over-financing is significantly greater than that of market value overvaluation.

We construct the following multiple linear regression model (7) to (9) to investigate the impacts of IPO over-financing and market value overvaluation on the size of the transaction. Table 4 presents the definitions of related variables.

$$
\begin{aligned}
& \text { M\&A_Size }=\alpha_{0}+\alpha_{1} I P O O F \_S i z e+\alpha_{2} M B+\alpha_{3} \text { Lev }+\alpha_{4} \text { Industry }+\alpha_{5} Y e a r+\zeta ; \\
& M \& A \_S i z e=\alpha_{0}+\alpha_{1} I P O O F \_S i z e+\alpha_{2} P p a+\alpha_{3} \text { Lev }+\alpha_{4} \text { Industry }+\alpha_{5} Y e a r+\zeta ; \\
& M \& A \_S i z e=\alpha_{0}+\alpha_{1} I P O O F \_S i z e+\alpha_{2} \text { Tobin's } Q+\alpha_{3} \text { Lev }+\alpha_{4} \text { Industry }+\alpha_{5} \text { Year }+\zeta .
\end{aligned}
$$

The regression coefficient of IPOOF_Size, which is the proxy for IPO over-financing, is predicted significantly positive in the model (7) to (9). The regression coefficient of $\mathrm{MB}$, Ppa and Tobin's Q, which are the proxies for market value overvaluation, are also predicted significantly positive.

The number of M\&A is bound to be a positive integer, which does not satisfy the assumption that dependent variables in OLS regression fall into positive and negative infinite continuous distribution. We construct the following Negative Binomial and Poisson regression model (10) to (15) to investigate the impacts of IPO over-financing and market value overvaluation on transaction frequency. Since a company may be involved in several M\&A in a year, MB_Ave, Ppa_Ave and Tobin's Q_Ave are used as proxies for market value overvaluation. Table 4 presents the definitions of related variables.

$$
\begin{aligned}
& \text { NegativeBinomial }\left(M \& A \_F r e q\right)=\theta_{0}+\theta_{1} I P O O F \_S i z e+\theta_{2} M B \_ \text {Ave }+ \\
& \theta_{3} \text { Lev_Ave }+\theta_{4} \text { Industry }+\theta_{5} \text { Year }+\zeta \text {; } \\
& \text { NegativeBinomial }\left(M \& A \_F r e q\right)=\theta_{0}+\theta_{1} I P O O F \_S i z e+\theta_{2} P p a \_A v e+ \\
& \theta_{3} \text { Lev_Ave }+\theta_{4} \text { Industry }+\theta_{5} \text { Year }+\zeta \text {; } \\
& \text { NegativeBinomial }\left(M \& A \_F r e q\right)=\theta_{0}+\theta_{1} I P O O F \_S i z e+\theta_{2} \text { Tobin'sQ_Ave + } \\
& \theta_{3} \text { Lev_Ave }+\theta_{4} \text { Industry }+\theta_{5} \text { Year }+\zeta \text {; } \\
& \text { Poisson }\left(M \& A \_ \text {Freq }\right)=\theta_{0}+\theta_{1} I P O O F \_ \text {Size }+\theta_{2} M B \_ \text {Ave }+ \\
& \theta_{3} \text { Lev_Ave }+\theta_{4} \text { Industry }+\theta_{5} \text { Year }+\zeta \text {; } \\
& \text { Poisson }\left(M \& A \_ \text {Freq }\right)=\theta_{0}+\theta_{1} I P O O F \_S i z e+\theta_{2} P p a \_ \text {Ave }+ \\
& \theta_{3} \text { Lev_Ave }+\theta_{4} \text { Industry }+\theta_{5} \text { Year }+\zeta \text {; } \\
& \text { Poisson }\left(M \& A \_F r e q\right)=\theta_{0}+\theta_{1} I P O O F \_S i z e+\theta_{2} \text { Tobin'sQ_Ave }+ \\
& \theta_{3} \text { Lev_Ave }+\theta_{4} \text { Industry }+\theta_{5} \text { Year }+\zeta \text {. }
\end{aligned}
$$

The regression coefficient of IPOOF_Size, which is the proxy for IPO over-financing, is predicted significantly positive in the model (10) to (15). The regression coefficient of MB_Ave, Ppa_Ave and Tobin's Q_Ave, which are the proxies for market value overvaluation, are also predicted significantly positive but smaller than the regression coefficient of IPOOF_Size. 
Table 4. Definitions of variables

\begin{tabular}{|c|c|c|c|}
\hline & Variable & Symbol & Definition \\
\hline \multirow{3}{*}{$\begin{array}{l}\text { Dependent } \\
\text { Variables }\end{array}$} & $\begin{array}{l}\text { The occurrence } \\
\text { of M\&A }\end{array}$ & M\&A_If & $\begin{array}{l}\text { Dummy variable; If the company is involved in } \\
\text { M\&A, the value is } 1 \text {; otherwise the value is } 0 .\end{array}$ \\
\hline & $\begin{array}{l}\text { The size of } \\
\text { M\&A }\end{array}$ & M\&A_Size & $\begin{array}{l}\text { M\&A_Size }=\text { Ln (the size of each } M \& A+1 \text { ); If there's } \\
\text { no M\&A, the value is } 0 .\end{array}$ \\
\hline & $\begin{array}{l}\text { Transaction } \\
\text { frequency }\end{array}$ & M\&A_Freq & $\begin{array}{l}\text { the number of M\&A happened in the year } \\
\text { of the company }\end{array}$ \\
\hline \multirow{8}{*}{$\begin{array}{l}\text { Explanatory } \\
\text { Variables }\end{array}$} & $\begin{array}{l}\text { The occurrence } \\
\text { of IPO over- } \\
\text { financing }\end{array}$ & IPOOF_If & $\begin{array}{l}\text { Dummy variable; If IPO over-financing exists, } \\
\text { the value is } 1 \text {; otherwise the value is } 0 \text {. }\end{array}$ \\
\hline & $\begin{array}{l}\text { The size of IPO } \\
\text { over-financing }\end{array}$ & IPOOF_Size & $\begin{array}{l}\text { IPOOF_Size }=\log _{10} \text { (the size of IPO over- } \\
\text { financing }+1 \text { ); If there's no IPO over-financing, } \\
\text { the value is } 0 \text {. }\end{array}$ \\
\hline & \multirow{6}{*}{$\begin{array}{l}\text { Market value } \\
\text { overvaluation }\end{array}$} & MB & $\begin{array}{l}\text { Market to book value ratio; } \mathrm{MB}=(\text { total market } \\
\text { value+total liabilities)/total assets; For companies } \\
\text { involved in M\&A, total market value refers to the } \\
\text { market value on the announcement day of M\&A. } \\
\text { Total liabilities and total assets come from the latest } \\
\text { financial statement before the announcement date } \\
\text { of M\&A. For other companies, it is the mean value } \\
\text { of the beginning and the end of the year. }\end{array}$ \\
\hline & & MB_Ave & $\begin{array}{l}\text { Average market to book value ratio; For companies } \\
\text { involved in M\&A, it is the mean value of MB } \\
\text { on every announcement day of M\&A. For other } \\
\text { companies, it is the mean value of the beginning } \\
\text { and the end of the year. }\end{array}$ \\
\hline & & Ppa & $\begin{array}{l}\text { Price to book value ratio; Ppa=closing price per } \\
\text { share/(total equity at the end of the period/paid-in } \\
\text { capital at the end of the period); For companies } \\
\text { involved in M\&A, it comes from the latest financial } \\
\text { statement before the announcement date of M\&A. } \\
\text { For other companies, it is the mean value of the } \\
\text { beginning and the end of the year. }\end{array}$ \\
\hline & & Ppa_Ave & $\begin{array}{l}\text { Average price to book value ratio; For companies } \\
\text { involved in M\&A, it is the mean value of Ppa } \\
\text { on every announcement day of M\&A. For other } \\
\text { companies, it is the mean value of the beginning } \\
\text { and the end of the year. }\end{array}$ \\
\hline & & Tobin's Q & $\begin{array}{l}\text { Tobin's } \mathrm{Q}=(\text { total market value }+ \text { total liabilities }) / \\
\text { replacement cost; For companies involved in } \\
\text { M\&A, it comes from the latest financial statement } \\
\text { before the announcement date of M\&A. For other } \\
\text { companies, it is the mean value of the beginning } \\
\text { and the end of the year. }\end{array}$ \\
\hline & & $\begin{array}{l}\text { Tobin's } \\
\text { Q_Ave }\end{array}$ & $\begin{array}{l}\text { Average Tobin's Q; For companies involved in } \\
\text { M\&A, it is the mean value of Tobin's Q on every } \\
\text { announcement day of M\&A. For other companies, it } \\
\text { is the mean value of the beginning and the end } \\
\text { of the year. }\end{array}$ \\
\hline
\end{tabular}


End of Table 4

\begin{tabular}{|l|l|l|l|}
\hline & \multicolumn{1}{|c|}{ Variable } & \multicolumn{1}{|c|}{ Symbol } & \multicolumn{1}{c|}{ Definition } \\
\hline \multirow{3}{*}{$\begin{array}{l}\text { Fontrol } \\
\text { Variables }\end{array}$} & Lev & & $\begin{array}{l}\text { Asset-liability ratio=total liabilities/total assets; } \\
\text { For companies involved in M\&A, it comes from the } \\
\text { latest financial statement before the announcement } \\
\text { date of M\&A. For other companies, it is the mean } \\
\text { value of the beginning and the end of the year. }\end{array}$ \\
\cline { 2 - 5 } & Year effects & Year & $\begin{array}{l}\text { Average asset-liability ratio; For companies involved } \\
\text { in M\&A, it is the mean value of the asset-liability } \\
\text { ratio on every announcement day of M\&A. For other } \\
\text { companies, it is the mean value of the beginning and } \\
\text { the end of the year. }\end{array}$ \\
\cline { 2 - 5 } & Industry effects & Industry & $\begin{array}{l}\text { We define 8 dummy variables, for which the } \\
\text { benchmark year is 2009. }\end{array}$ \\
\cline { 2 - 4 } & & $\begin{array}{l}\text { First-level industry classification according to the } \\
\text { CSRC industry standard; we define 13 dummy } \\
\text { variables for which the benchmark is A representing } \\
\text { the agriculture, forestry, animal Husbandry } \\
\text { and fishery industry. }\end{array}$ \\
\hline
\end{tabular}

\subsection{Methodology to calculate Cumulative Abnormal Returns}

This paper examines the market reaction to various payment methods following the method of event study. Following existing literature (Fuller et al., 2002; Moeller et al., 2004; Dong et al., 2006), we use CAR (Cumulative Abnormal Returns) calculated with the market adjustment method as the measurement of market reaction. The specific calculation is shown as below.

$$
A R_{i}=R_{i}-R_{m}
$$

$R_{i}$ represents the yield of ChiNext company i. $R_{m}$ is the market return. Since Growth Enterprise Index isn't officially released until June 1st, 2010. We measure the market return before June 1st, 2010 with the return of SME Index.

Based on previous research literature (Fuller et al., 2002; Moeller et al., 2004; Dong et al., 2006), market reaction is measured by $\operatorname{CAR}(-1,1)$ of 3 days around the first announcement date of M\&A and CAR $(-2,2)$ of 5 days around the first announcement date of M\&A. Because M\&A information is often released before the announcement date, too small windows may miss the early responses to market while too large windows probably involve the reaction to other events. Learning from existing literature (Lang et al., 1991), we have also calculated CAR $(-3,3)$ of 7 days around the first announcement date of M\&A, CAR $(-4,4)$ of 9 days around the first announcement date of M\&A and CAR $(-5,5)$ of 11 days around the first announcement date of M\&A to obtain robust results.

This paper takes 2206 M\&A transactions in ChiNext companies from 2009 to 2016 as research samples. We omit 681 transactions that do not disclose complete transaction data on the announcement day. We omit 49 transactions that do not disclose payment method. Two or more M\&A transactions disclosed by one company on the same trading day will bring about repeated calculation of market reaction. So we have also removed the related 130 transactions. Eventually our samples consist of 1346 M\&A transactions. 


\section{Empirical results}

\subsection{Descriptive statistics}

Table 5 reports on the annual distribution and frequency of M\&A in the ChiNext market. We can see from panel A that the ChiNext market has seen a wave of M\&A. Numbers of companies involved in M\&A and M\&A transactions have been increasing sharply from 2010 to 2016. In 2010 there's only 24 companies involved in 44 M\&A transactions, while in 2015 there were 301 companies involved in $724 \mathrm{M} \& \mathrm{~A}$ transactions. In the single year of 2015 there were 301 out of 492 ChiNext companies involved in M\&A transactions, making up $61.18 \%$ of all the listed companies in the ChiNext market. In total 724 M\&A took place in 2015, so on average at least one M\&A happens on every trading day.

It's worth noting that all the targets of M\&A in the ChiNext market are non-listed companies, which is quite different to the American and European market where a significant portion of targets are listed companies (Chang, 1998; Harford, 2005; Moeller et al., 2005; Betton et al., 2008; Eckbo, 2009; Maksimovic et al., 2013).

Panel B shows that high-frequency M\&A of a single company is getting increasingly popular in the ChiNext market. Large number of ChiNext companies conducted high-frequency sequent M\&As from 2010 to 2016, and the number continues to go up. 178 companies were involved in at least two M\&A transactions in the year of 2015, making up $36.18 \%$ of all the listed companies in the ChiNext market. BlueFocus Communication Group Co., Ltd. (300058), acclaimed as the NO.1 stock of public relations by the media, conducted $31 \mathrm{M} \& \mathrm{~A}$ transactions in the year of 2014 only. This makes BlueFocus the company that has most frequent M\&A transactions since the stock market was founded in China in 1990, which can be regarded as a reflection of the madness in this rising wave of M\&A.

As we can see from Table 6, there are 1801 M\&A transactions paid with cash by ChiNext companies. Cash payment was the primary payment method, making up $81.64 \%$ of all M\&A, which is much higher than the proportion of that in the United States and Europe (Servaes, 1991; Faccio \& Masulis, 2005; Rhodes-Kropf et al., 2005; Martynova \& Renneboog, 2009). The reason of the difference is associated with the great amount of IPO over-financing. Besides, stock payment and cash and stock mixed payment are getting more and more popular with continuous upsurge in the ChiNext market. 67 uses of stock payment and 269 uses of cash and stock mixed payment make up 3.04\% and $12.19 \%$ of all M\&A activities, respectively, though still a low number compared to that of cash payment.

Table 7 shows the relationship between IPO over-financing, market value overvaluation and payment methods. It can be seen from Panel A that in the case of 1801 cash payments, 1560 were carried out by companies with IPO over-financing, constituting $86.62 \%$ of all transactions. IPO over-financing leads to enterprises' preference of cash payment. In order to find out the extent of market value overvaluation, we compare the MB of the ChiNext companies on the announcement day of M\&A to the average MB of four quarters in the same year of mainboard companies in Panel B. Data in panel B shows that market value overvaluation is widespread among companies using stock payments. 37 out of 59 stock payments were carried out by companies with market value overvaluation. More and more ChiNext companies are going to use overvalued stock for M\&A as regulatory authorities encourage the use of a variety of payment methods under the continuous upsurge in the ChiNext market. 


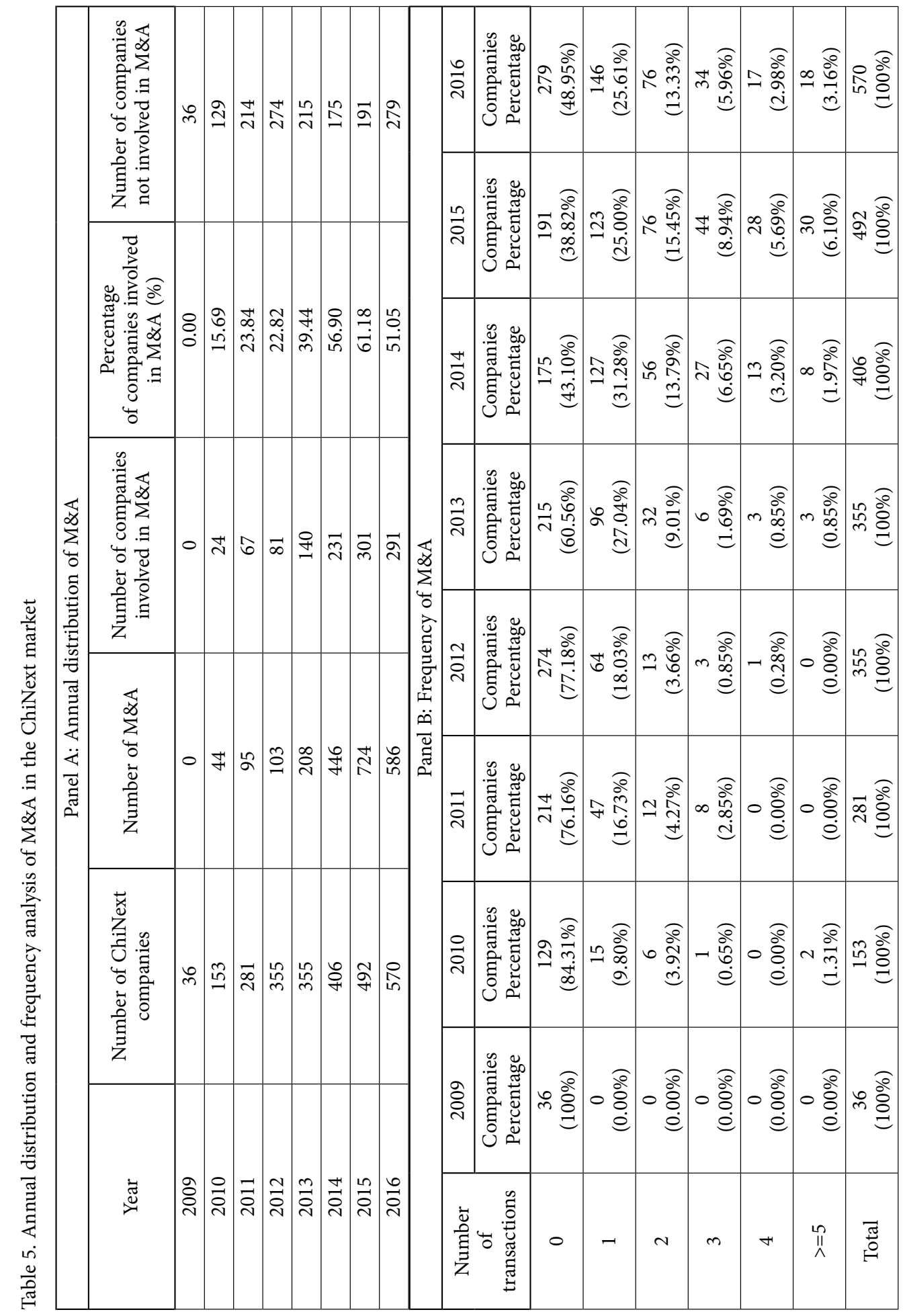


Table 6. Descriptive statistics of method of payment

\begin{tabular}{|c|c|c|c|c|c|c|c|c|c|c|}
\hline \multirow[b]{2}{*}{ Year } & \multicolumn{2}{|c|}{ Cash payment } & \multicolumn{2}{|c|}{ Stock payment } & \multicolumn{2}{|c|}{$\begin{array}{l}\text { Cash and stock } \\
\text { mixed payment }\end{array}$} & \multicolumn{2}{|c|}{$\begin{array}{l}\text { Other payment } \\
\text { methods }\end{array}$} & \multicolumn{2}{|c|}{ Not disclosed } \\
\hline & $\begin{array}{l}\check{\Xi} \\
\stackrel{\Xi}{\Xi} \\
z\end{array}$ & 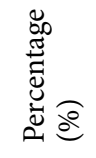 & 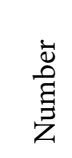 & 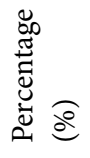 & 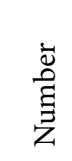 & 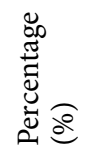 & $\begin{array}{l}\dot{\Xi} \\
\text { हे } \\
\text { ż }\end{array}$ & 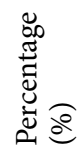 & $\begin{array}{l}\ddot{\Xi} \\
\text { हे } \\
\text { ż }\end{array}$ & 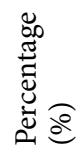 \\
\hline 2009 & 0 & - & 0 & - & 0 & - & 0 & - & 0 & - \\
\hline 2010 & 44 & 100.00 & 0 & 0.00 & 0 & 0.00 & 0 & 0.00 & 0 & 0.00 \\
\hline 2011 & 91 & 95.79 & 0 & 0.00 & 3 & 3.16 & 0 & 0.00 & 1 & 1.05 \\
\hline 2012 & 93 & 90.29 & 5 & 4.85 & 2 & 1.94 & 0 & 0.00 & 3 & 2.91 \\
\hline 2013 & 162 & 77.88 & 10 & 4.81 & 32 & 15.38 & 1 & 0.48 & 3 & 1.44 \\
\hline 2014 & 347 & 77.80 & 12 & 2.69 & 67 & 15.02 & 7 & 1.57 & 13 & 2.91 \\
\hline 2015 & 573 & 79.14 & 32 & 4.42 & 95 & 13.12 & 5 & 0.69 & 19 & 2.62 \\
\hline 2016 & 491 & 83.79 & 8 & 1.37 & 70 & 11.95 & 7 & 1.19 & 10 & 1.71 \\
\hline Total & 1801 & 81.64 & 67 & 3.04 & 269 & 12.19 & 20 & 0.91 & 49 & 2.22 \\
\hline
\end{tabular}

Note: other payment methods consist of asset payment, claims payment and so on.

Table 7. IPO Over-financing, market overvaluation and method of payment

\begin{tabular}{|c|c|c|c|}
\hline \multicolumn{4}{|c|}{ Panel A: IPO over-financing and cash payment } \\
\hline Year & Times of cash payment & $\begin{array}{c}\text { Cash payment under IPO } \\
\text { over-financing }\end{array}$ & Percentage (\%) \\
\hline 2009 & 0 & 0 & - \\
\hline 2010 & 44 & 44 & 100.00 \\
\hline 2011 & 91 & 91 & 100.00 \\
\hline 2012 & 93 & 91 & 97.85 \\
\hline 2013 & 162 & 162 & 100.00 \\
\hline 2014 & 347 & 328 & 94.52 \\
\hline 2015 & 573 & 476 & 83.07 \\
\hline 2016 & 491 & 368 & 74.95 \\
\hline Total & 1801 & 1560 & 86.62 \\
\hline \multicolumn{4}{|c|}{ Panel B: Market overvaluation and stock payment } \\
\hline Year & Times of stock payment & $\begin{array}{c}\text { Stock payment under } \\
\text { market value overvaluation }\end{array}$ & Percentage (\%) \\
\hline 2009 & 0 & 0 & - \\
\hline 2010 & 0 & 0 & - \\
\hline 2011 & 0 & 0 & - \\
\hline 2012 & 5 & 0 & 0.00 \\
\hline 2013 & $8^{\#}$ & 7 & 87.50 \\
\hline 2014 & 12 & 11 & 91.67 \\
\hline 2015 & $29^{\# \#}$ & 15 & 51.72 \\
\hline 2016 & $5^{\# \# \#}$ & 4 & 80.00 \\
\hline Total & 59 & 37 & 62.71 \\
\hline
\end{tabular}


End of Table 7

\begin{tabular}{|c|c|c|c|c|c|c|c|}
\hline \multicolumn{7}{|c|}{ Panel C: IPO over-financing, market overvaluation and mixed payment } \\
\hline Year & $\begin{array}{c}\text { Times of } \\
\text { cash and } \\
\text { stock } \\
\text { mixed } \\
\text { payment }\end{array}$ & $\begin{array}{c}\text { Mixed } \\
\text { payment under } \\
\text { IPO over- } \\
\text { financing }\end{array}$ & $\begin{array}{c}\text { Per- } \\
\text { centage } \\
(\%)\end{array}$ & $\begin{array}{c}\text { Mixed } \\
\text { payment } \\
\text { under } \\
\text { market value } \\
\text { overvaluation }\end{array}$ & $\begin{array}{c}\text { Per- } \\
\text { centage } \\
(\%)\end{array}$ & $\begin{array}{c}\text { Mixed payment } \\
\text { under both IPO } \\
\text { over-financing } \\
\text { and market value } \\
\text { overvaluation }\end{array}$ & $\begin{array}{c}\text { Per- } \\
\text { centage } \\
(\%)\end{array}$ \\
\hline 2009 & 0 & 0 & - & 0 & - & 0 & - \\
\hline 2010 & 0 & 0 & - & 0 & - & 0 & - \\
\hline 2011 & 3 & 3 & 100.00 & 3 & 100.00 & 3 & 100.00 \\
\hline 2012 & 2 & 2 & 100.00 & 2 & 100.00 & 2 & 100.00 \\
\hline 2013 & $30^{*}$ & 28 & 93.33 & 30 & 100.00 & 28 & 93.33 \\
\hline 2014 & 67 & 61 & 91.04 & 62 & 92.54 & 57 & 85.07 \\
\hline 2015 & $93^{* *}$ & 77 & 82.80 & 57 & 61.29 & 47 & 50.54 \\
\hline 2016 & $66^{* * *}$ & 41 & 62.12 & 38 & 57.58 & 20 & 30.30 \\
\hline Total & 261 & 212 & 81.23 & 192 & 73.56 & 157 & 60.15 \\
\hline
\end{tabular}

Note: \# indicates 10 M\&A transactions paid with stock payment in 2013, two of which involved ChiNext companies without comparable main board companies in the same industry. Because we can't tell whether the market value is overvalued or not, the referred two M\&A samples are omitted. \#\# denotes that 32 M\&A transactions paid with stock payment in 2015, two of which involved ChiNext companies without comparable main board companies in the same industry. Because we can't tell whether the market value is overvalued or not, the referred three M\&A samples are omitted. \#\#\#denotes that $8 \mathrm{M} \& \mathrm{~A}$ transactions paid with stock payment in 2016, three of which involved ChiNext companies without comparable main board companies in the same industry. Because we can't tell whether the market value is overvalued or not, the referred three M\&A samples are omitted. * denotes that 32 M\&A transactions paid with cash and stock mixed payment in 2013, two of which involved ChiNext companies without comparable main board companies in the same industry. Because we can't tell whether the market value is overvalued or not, the referred two M\&A samples are omitted. ${ }^{* *}$ denotes that $95 \mathrm{M} \& \mathrm{~A}$ transactions paid with cash and stock mixed payment in 2015, two of which involved ChiNext companies without comparable main board companies in the same industry. Because we can't tell whether the market value is overvalued or not, the referred two M\&A samples are omitted. ${ }^{\star * \star}$ denotes that $70 \mathrm{M} \& \mathrm{~A}$ transactions paid with cash and stock mixed payment in 2016, three of which involved ChiNext companies without comparable main board companies in the same industry. Because we can't tell whether the market value is overvalued or not, the referred four M\&A samples are omitted.

It's shown in Panel C that 212 out of 261 cash and stock mixed payments are associated with companies with IPO over-financing, accounting for a proportion of $81.23 \%$. 192 out of 261 cash and stock mixed payments are associated with companies with market value overvaluation, accounting for a proportion of $73.56 \% .157$ out of 261 cash and stock mixed payments are associated with companies with both IPO over-financing and market value overvaluation, accounting for a proportion of $60.15 \%$. Thus, IPO over-financing and market value overvaluation promote the use of cash and stock mixed payment.

Table 8 displays the industry distribution of M\&A in the ChiNext market. 431 out of 570 ChiNext companies have conducted 2206 M\&A as of the end of 2016. M\&A transactions exist in every industry, but they are much more frequent in certain industries. $64.91 \%$ of M\&A transactions take place in Pharmaceutical Manufacturing (C27, 171 times), General Equipment \& Special Equipment Manufacturing (C34, C35, 338 times), Electrical Machinery and 
Table 8. Industry distribution of M\&A in the ChiNext market

\begin{tabular}{|c|c|c|c|c|}
\hline Industry & 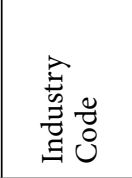 & 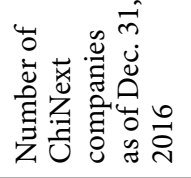 & 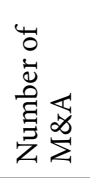 & 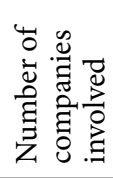 \\
\hline Agriculture, Forestry, Animal Husbandry and Fishery & A & 8 & 26 & 7 \\
\hline Mining & B & 4 & 43 & 4 \\
\hline $\begin{array}{l}\text { Agricultural and Sideline Food Processing, Food } \\
\text { Manufacturing }\end{array}$ & C13 C14 & 7 & 28 & 6 \\
\hline Textile and Apparel & $\mathrm{C} 18$ & 1 & 12 & 1 \\
\hline $\begin{array}{l}\text { Education, Crafts, Sports \& Fitness, Entertainment } \\
\text { Products Manufacturing }\end{array}$ & $\mathrm{C} 24$ & 2 & 7 & 1 \\
\hline $\begin{array}{l}\text { Chemical Raw Materials and Chemical Products } \\
\text { Manufacturing }\end{array}$ & $\mathrm{C} 26$ & 38 & 106 & 24 \\
\hline Pharmaceutical Manufacturing & $\mathrm{C} 27$ & 42 & 171 & 32 \\
\hline Rubber and Plastic Products & $\mathrm{C} 29$ & 15 & 54 & 10 \\
\hline Non-Metallic Mineral Products & $\mathrm{C} 30$ & 15 & 38 & 12 \\
\hline $\begin{array}{l}\text { Non-Ferrous Metal Smelting and Rolling Processing, } \\
\text { Metal Products }\end{array}$ & C32 C33 & 9 & 25 & 9 \\
\hline $\begin{array}{l}\text { General Equipment, Special Equipment } \\
\text { Manufacturing }\end{array}$ & C34 C35 & 97 & 338 & 73 \\
\hline $\begin{array}{l}\text { Automobile, Railway, Ship, Aerospace and Other } \\
\text { Transportation Equipment Manufacturing }\end{array}$ & C36 C37 & 10 & 28 & 8 \\
\hline $\begin{array}{l}\text { Electrical Machinery and Equipment, Computers, } \\
\text { Communication and Other Electronic Equipment, } \\
\text { Instrumentation Manufacturing }\end{array}$ & $\begin{array}{c}\text { C38 C39 } \\
\text { C40 }\end{array}$ & 159 & 565 & 119 \\
\hline Other Manufacturing & $\mathrm{C} 41$ & 3 & 17 & 3 \\
\hline $\begin{array}{l}\text { Electricity, Heat, Gas and Water Production and } \\
\text { Supply }\end{array}$ & $\mathrm{D}$ & 2 & 8 & 2 \\
\hline Construction & E & 9 & 20 & 4 \\
\hline Wholesale and Retail & $\mathrm{F}$ & 6 & 19 & 5 \\
\hline Transportation, Warehousing and Postal Services & G & 3 & 13 & 3 \\
\hline $\begin{array}{l}\text { Telecommunications, Radio and Television and } \\
\text { Satellite Transmission Services, the Internet and } \\
\text { Related Services }\end{array}$ & I63 I64 & 18 & 69 & 13 \\
\hline Software and Information Technology Services & I65 & 86 & 358 & 65 \\
\hline Leasing and Business Services & $\mathrm{L}$ & 6 & 76 & 4 \\
\hline Scientific Research and Technical Services & M & 9 & 38 & 8 \\
\hline Water, Environment and Public Facilities Management & $\mathrm{N}$ & 8 & 26 & 6 \\
\hline Health and Social Work & Q & 3 & 38 & 3 \\
\hline Culture, Sports \& Fitness, Entertainment & $\mathrm{R}$ & 10 & 83 & 9 \\
\hline Total & - & 570 & 2206 & 431 \\
\hline
\end{tabular}


Equipment \& Computers \& Communication \& Other Electronic Equipment \& Instrumentation Manufacturing (C38, C39, C40, 565 times) and Software and Information Technology Services (I65, 358 times).

We can draw the conclusion that IPO over-financing and market value overvaluation are typical characteristics of the ChiNext market based on the descriptive statistics in Table 9. 357 out of 570 ChiNext companies have had IPO over-financing as of the end of 2016. The mean value of IPOOF_If is 0.8521 , indicating that the majority of ChiNext companies are experiencing IPO over-financing. Mean values of proxies for market value overvaluation, including MB, Ppa, Tobin's Q, MB_Ave, Ppa_Ave and Tobin's Q_Ave, are 4.8821, 6.1004, $4.7289,4.4487,5.4604$ and 4.3394 , respectively, which are higher than the corresponding market indicators in the United States and Europe (Rhodes-Kropf et al., 2005; Faccio \& Masulis, 2005). It proves that most ChiNext companies have been overvalued due to the continuous upsurge in the ChiNext market.

Moreover, mean values of Lev and Lev_Ave are 0.2439 and 0.2271 , respectively, indicating the low financial risks of ChiNext companies. Standard deviations of Lev and Lev_Ave are 0.1575 and 0.1525 , respectively, which are fairly low compared to the SME and the main board stock market as is expected. Further evidence has been provided that, thanks to IPO over-financing and market value overvaluation, the adequate liquidity owned by ChiNext companies makes debts unnecessary. The average M\&A_If of 2106 M\&A transactions is 0.5821. The average M\&A_Size is 10.2931. The standard deviation of M\&A_Size is 8.8291, reflecting the significant difference in the size of transactions among sample companies. The mean value of M\&A_Freq is 0.8313 , meaning that on average each ChiNext company carries out $0.8313 \mathrm{M} \& \mathrm{~A}$ per year.

Table 9. Descriptive statistics

\begin{tabular}{|l|c|c|c|c|c|c|c|c|}
\hline \multicolumn{7}{|c|}{ Panel A: Samples based on the number of M\&A } \\
\hline \multicolumn{1}{|c|}{ Variables } & Observations & Mean & Std. Dev. & Min & Max & $25 \%$ & Median & $75 \%$ \\
\hline M\&A_If & 3618 & 0.5821 & 0.4933 & 0.0000 & 1.0000 & 0.0000 & 1.0000 & 1.0000 \\
\hline M\&A_Size & 3618 & 10.2931 & 8.8291 & 0.0000 & 23.2082 & 0.0000 & 15.8950 & 17.9125 \\
\hline IPOOF_If & 3618 & 0.8521 & 0.3550 & 0.0000 & 1.0000 & 1.0000 & 1.0000 & 1.0000 \\
\hline IPOOF_Size & 3618 & 7.1480 & 3.0244 & 0.0000 & 9.2933 & 7.9856 & 8.3770 & 8.6637 \\
\hline MB & 3618 & 4.8821 & 4.2242 & 0.9535 & 78.8347 & 2.6158 & 3.7982 & 5.6484 \\
\hline Ppa & 3618 & 6.1004 & 5.4795 & 0.8806 & 76.1270 & 3.0655 & 4.7105 & 7.3064 \\
\hline Tobin's Q & 3618 & 4.7289 & 4.2389 & 0.9364 & 61.6280 & 2.5563 & 3.6723 & 5.5893 \\
\hline Lev & 3618 & 0.2439 & 0.1575 & 0.0002 & 0.9043 & 0.1190 & 0.2129 & 0.3384 \\
\hline \multicolumn{1}{|c|}{ Variables } & Observations & Mean & Std. Dev. & Min & Max & $25 \%$ & Median & $75 \%$ \\
\hline M\&A_Freq & 2632 & 0.8313 & 1.4795 & 0.0000 & 31.0000 & 0.0000 & 0.0000 & 1.0000 \\
\hline IPOOF_Size & 2632 & 7.0932 & 3.0700 & 0.0000 & 9.2933 & 7.9643 & 8.3770 & 8.6478 \\
\hline MB_Ave & 2632 & 4.4487 & 3.2431 & 0.9588 & 46.5581 & 2.4378 & 3.5586 & 5.2691 \\
\hline Ppa_Ave & 2632 & 5.4604 & 4.0748 & 0.8806 & 52.4677 & 2.8368 & 4.3183 & 6.6918 \\
\hline Tobin's Q_Ave & 2632 & 4.3394 & 3.1174 & 0.9364 & 49.1503 & 2.3836 & 3.4993 & 5.1880 \\
\hline Lev_Ave & 2632 & 0.2271 & 0.1525 & 0.0049 & 0.9043 & 0.1062 & 0.1947 & 0.3157 \\
\hline
\end{tabular}




\subsection{IPO over-financing, market overvaluation and acquisition probability}

Table 10 examines the impacts of IPO over-financing and market value overvaluation on M\&A in terms of acquisition probability. As shown model (1) to (3) in Panel A, IPOOF_If is positively related to M\&A_If. The regression coefficients of which are 1.274, 1.199 and 1.191, respectively. All the coefficients are significant at the $1 \%$ level. Besides, there's a significant positive relation between MB, Ppa, Tobin's Q and M\&A_If. The regression coefficients are $0.0923,0.0501$ and 0.0577 , respectively, all of which are significant at the $1 \%$ level. So it has been confirmed that IPO over-financing and market value overvaluation are the effective driving forces of $M \& A$.

Table 10. IPO Over-financing, market overvaluation and acquisition probability

\begin{tabular}{|c|c|c|c|c|c|c|c|}
\hline \multicolumn{8}{|c|}{ Panel A: Applying IPOOF_If as a proxy for IPO over-financing } \\
\hline \multirow{2}{*}{ Variables } & \multirow{2}{*}{$\begin{array}{l}\text { Predicted } \\
\text { Sign }\end{array}$} & Model (1) & \multirow{2}{*}{$\begin{array}{l}\text { Marginal } \\
\text { effects }\end{array}$} & Model (2) & \multirow{2}{*}{$\begin{array}{l}\text { Marginal } \\
\text { effects }\end{array}$} & Model (3) & \multirow{2}{*}{$\begin{array}{c}\text { Marginal } \\
\text { effects }\end{array}$} \\
\hline & & M\&A_If & & M\&A_If & & M\&A_If & \\
\hline IPOOF_If & + & $\begin{array}{c}1.274^{\star * *} \\
(0.000)\end{array}$ & $\begin{array}{c}0.3064^{\star * *} \\
(0.000)\end{array}$ & $\begin{array}{c}1.199^{* * *} \\
(0.000)\end{array}$ & $\begin{array}{c}0.2897^{\star * *} \\
(0.000)\end{array}$ & $\begin{array}{c}1.191^{\star * *} \\
(0.000)\end{array}$ & $\begin{array}{c}0.2879^{* * *} \\
(0.000)\end{array}$ \\
\hline MB & + & $\begin{array}{c}0.0923^{* * *} \\
(0.000)\end{array}$ & $\begin{array}{c}0.0226^{* * *} \\
(0.000)\end{array}$ & & & & \\
\hline Ppa & + & & & $\begin{array}{c}0.0501^{* * *} \\
(0.000)\end{array}$ & $\begin{array}{c}0.0123^{* * *} \\
(0.000)\end{array}$ & & \\
\hline Tobin's Q & + & & & & & $\begin{array}{c}0.0577^{\star * *} \\
(0.000)\end{array}$ & $\begin{array}{c}0.0142^{\star * *} \\
(0.000)\end{array}$ \\
\hline Lev & + & $\begin{array}{c}0.920^{\star * *} \\
(0.001)\end{array}$ & $\begin{array}{c}0.2254^{* * *} \\
(0.001)\end{array}$ & $0.413(0.131)$ & $\begin{array}{l}0.1014 \\
(0.131)\end{array}$ & $\begin{array}{c}0.722^{\star * *} \\
(0.009)\end{array}$ & $\begin{array}{c}0.1771^{\star * *} \\
(0.009)\end{array}$ \\
\hline Constant & $?$ & $\begin{array}{c}0.333 \\
(0.293)\end{array}$ & & $\begin{array}{l}0.661^{\star *} \\
(0.031)\end{array}$ & & $\begin{array}{l}0.635^{\star *} \\
(0.043)\end{array}$ & \\
\hline Year & & Yes & & Yes & & Yes & \\
\hline Industry & & Yes & & Yes & & Yes & \\
\hline Wald chi2 & & $5709.62^{\star * *}$ & & $5606.13^{* * *}$ & & $5471.15^{\star * *}$ & \\
\hline Prob > chi2 & & 0.0000 & & 0.0000 & & 0.0000 & \\
\hline Pseudo $\mathrm{R}^{2}$ & & 0.1798 & & 0.1761 & & 0.1752 & \\
\hline $\mathrm{N}$ & & 3618 & & 3618 & & 3618 & \\
\hline \multicolumn{8}{|c|}{ Panel B: Applying IPOOF_Size as a proxy for IPO over-financing } \\
\hline \multirow{2}{*}{ Variables } & \multirow{2}{*}{$\begin{array}{l}\text { Predicted } \\
\text { Sign }\end{array}$} & Model (4) & \multirow{2}{*}{$\begin{array}{c}\text { Marginal } \\
\text { effects }\end{array}$} & Model (5) & \multirow{2}{*}{$\begin{array}{c}\text { Marginal } \\
\text { effects }\end{array}$} & Model (6) & \multirow{2}{*}{$\begin{array}{c}\text { Marginal } \\
\text { effects }\end{array}$} \\
\hline & & M\&A_If & & M\&A_If & & M\&A_If & \\
\hline IPOOF_Size & + & $\begin{array}{c}0.161^{* * *} \\
(0.000)\end{array}$ & $\begin{array}{c}0.0395^{\star * *} \\
(0.000)\end{array}$ & $\begin{array}{c}0.152^{\star * *} \\
(0.000)\end{array}$ & $\begin{array}{c}0.0373^{* * *} \\
(0.000)\end{array}$ & $\begin{array}{c}0.151^{\star * *} \\
(0.000)\end{array}$ & $\begin{array}{c}0.0369^{* * *} \\
(0.000)\end{array}$ \\
\hline MB & + & $\begin{array}{c}0.100^{* * *} \\
(0.000)\end{array}$ & $\begin{array}{c}0.0245^{\star * *} \\
(0.000)\end{array}$ & & & & \\
\hline Ppa & + & & & $\begin{array}{c}0.0555^{\star * *} \\
(0.000)\end{array}$ & $\begin{array}{c}0.0136^{* * *} \\
(0.000)\end{array}$ & & \\
\hline Tobin's Q & + & & & & & $\begin{array}{c}0.0647^{* * *} \\
(0.000)\end{array}$ & $\begin{array}{c}0.0159^{* * *} \\
(0.000)\end{array}$ \\
\hline
\end{tabular}


End of Table 10

\begin{tabular}{|l|c|c|c|c|c|c|c|}
\hline Lev & + & $\begin{array}{c}1.005^{\star * *} \\
(0.000)\end{array}$ & $\begin{array}{c}0.2463^{* * *} \\
(0.000)\end{array}$ & $0.453(0.101)$ & $\begin{array}{c}0.1112 \\
(0.101)\end{array}$ & $\begin{array}{c}0.796^{\star * *} \\
(0.004)\end{array}$ & $\begin{array}{c}0.1951^{\star * *} \\
(0.004)\end{array}$ \\
\hline Constant & $?$ & $\begin{array}{c}0.179 \\
(0.575)\end{array}$ & & $\begin{array}{c}0.526^{*} \\
(0.090)\end{array}$ & & $\begin{array}{c}0.492 \\
(0.121)\end{array}$ & \\
\hline Year & & Yes & & Yes & & Yes & \\
\hline Industry & & Yes & & Yes & & Yes & \\
\hline Wald chi2 & & $6255.46^{\star * *}$ & & $1164.83^{* * *}$ & & $5384.49^{* * *}$ & \\
\hline Prob > chi2 & & 0.0000 & & 0.0000 & & 0.0000 & \\
\hline Pseudo R & & 0.1829 & & 0.1789 & & 0.1779 & \\
\hline N & & 3618 & & 3618 & & 3618 & \\
\hline
\end{tabular}

Note: p-values are shown in parentheses; the logit regression model is used; standard deviations are performed Robust process; ${ }^{*}{ }^{* *}$ and ${ }^{* * *}$ represent the results are significant at the $10 \%$ level, the $5 \%$ level and the $1 \%$ level, respectively.

Through the marginal effect analysis of logit regression model from (1) to (3), we have identified IPO over-financing (IPOOF_If) as the explanatory variable that has the greatest impact on acquisition probability (M\&A_If $=1$ ). The marginal effects of IPO over-financing in model (1) to (3) are $0.3064,0.2897$ and 0.2879 , respectively. All of the marginal effects, which are significant at the $1 \%$ level, are much greater than those of $\mathrm{MB}$, Ppa and Tobin's $\mathrm{Q}(0.3064>0.0226 ; 0.2897>0.0123 ; 0.2879>0.0142)$. It's safe to conclude that, rather than market value overvaluation, IPO over-financing is the major driving factor for China's M\&A.

Furthermore, the results in model (4) to (6) in Panel B are consistent with those in model (1) to (3), which provide further evidence. Therefore, both IPO over-financing and market value overestimation cause enterprises' M\&A from the viewpoint of acquisition probability. Compared to market value overvaluation, IPO over-financing is the major driving factor for China's M\&A.

\subsection{IPO over-financing, market overvaluation and the size of transactions}

Table 11 examines the impacts of IPO over-financing and market value overvaluation on M\&A in terms of the size of transactions. F-statistics of all models are significant at the $1 \%$ level, indicating a high fitting precision. All the values of adjusted $R^{2}$ are greater than $20 \%$, signifying that the explanation is reliable. IPOOF_Size is positively related to M\&A_Size in model (7) to (9), the regression coefficients of which are $0.568,0.545$ and 0.549 , respectively. All the coefficients are significant at the $1 \%$ level. So it's convincing that heavier IPO overfinancing leads to larger scale of M\&A transactions.

Besides, there's a significant positive relation between MB, Ppa, Tobin's Q and M\&A_Size. The regression coefficients are $0.237,0.145$ and 0.178 , respectively, all of which are significant at the $1 \%$ level. This shows that companies will make use of overvalued stock to acquire other companies under market value overvaluation. Also, greater overvaluation contributes to greater size of transactions. Therefore, in terms of the scale of mergers and acquisitions, this paper supports the opinion that IPO over-financing and market value overvaluation are the main drivers of mergers and acquisitions. 
Table 11. IPO over-financing, market overvaluation and the size of transactions

\begin{tabular}{|c|c|c|c|c|}
\hline \multirow{2}{*}{ Variables } & \multirow{2}{*}{ Predicted Sign } & Model (7) & Model (8) & Model (9) \\
\hline & & M\&A_Size & M\&A_Size & M\&A_Size \\
\hline IPOOF_Size & + & $\begin{array}{c}0.568^{\star \star *} \\
(0.000)\end{array}$ & $\begin{array}{c}0.545^{\star * *} \\
(0.000)\end{array}$ & $\begin{array}{c}0.549^{* * *} \\
(0.000)\end{array}$ \\
\hline MB & + & $\begin{array}{c}0.237^{* * *} \\
(0.000)\end{array}$ & & \\
\hline Ppa & + & & $\begin{array}{c}0.145^{\star \star \star} \\
(0.000)\end{array}$ & \\
\hline Tobin's Q & + & & & $\begin{array}{c}0.178^{* * *} \\
(0.000)\end{array}$ \\
\hline Lev & + & $\begin{array}{c}2.541^{\star * *} \\
(0.007)\end{array}$ & $\begin{array}{c}1.005 \\
(0.276)\end{array}$ & $\begin{array}{l}2.128^{\star \star} \\
(0.023)\end{array}$ \\
\hline Constant & $?$ & $\begin{array}{l}-2.589 \\
(0.134)\end{array}$ & $\begin{array}{l}-1.842 \\
(0.286)\end{array}$ & $\begin{array}{l}-2.137 \\
(0.218)\end{array}$ \\
\hline Year & & Yes & Yes & Yes \\
\hline Industry & & Yes & Yes & Yes \\
\hline Adj. $\mathrm{R}^{2}$ & & $21.97 \%$ & $21.65 \%$ & $21.59 \%$ \\
\hline F-statistics & & $164.60^{\star * *}$ & $162.28^{\star * *}$ & $160.85^{\star * *}$ \\
\hline Prob $>$ F & & 0.0000 & 0.0000 & 0.0000 \\
\hline $\mathrm{N}$ & & 3618 & 3618 & 3618 \\
\hline
\end{tabular}

Note: $\mathrm{p}$-values are shown in parentheses; standard deviations are performed Robust process; ${ }^{*},{ }^{*}$ and ${ }^{* * *}$ represent the results are significant at the $10 \%$ level, the $5 \%$ level and the $1 \%$ level, respectively.

We use a sample of merged companies every year and conduct a robust test. From 2009 to 2016 , the number of merged companies is $0,24,67,81,140,231,296$ and 281 respectively, so we get 1120 observations. Table 12 reports the results.

Table 12. Robust test: IPO over-financing, market overvaluation and the size of transactions

\begin{tabular}{|c|c|c|c|c|}
\hline \multirow{2}{*}{ Variables } & \multirow{2}{*}{ Predicted Sign } & Model (7) & Model (8) & Model (9) \\
\hline & & M\&A_Size & M\&A_Size & M\&A_Size \\
\hline IPOOF_Size & + & $\begin{array}{l}0.0314^{\star} \\
(0.094)\end{array}$ & $\begin{array}{l}0.0337^{\star} \\
(0.070)\end{array}$ & $\begin{array}{l}0.0318^{\star} \\
(0.090)\end{array}$ \\
\hline MB & + & $\begin{array}{l}0.0253^{\star} \\
(0.078)\end{array}$ & & \\
\hline Ppa & + & & $\begin{array}{c}0.0298^{\star *} \\
(0.014)\end{array}$ & \\
\hline Tobin's Q & + & & & $\begin{array}{l}0.0281^{*} \\
(0.076)\end{array}$ \\
\hline Lev & + & $\begin{array}{l}0.965^{\star *} \\
(0.013)\end{array}$ & $\begin{array}{l}0.775^{\star *} \\
(0.040)\end{array}$ & $\begin{array}{l}0.967^{\star *} \\
(0.013)\end{array}$ \\
\hline Constant & $?$ & $\begin{array}{c}16.02^{\star * *} \\
(0.000)\end{array}$ & $\begin{array}{c}16.02^{\star * *} \\
(0.000)\end{array}$ & $\begin{array}{c}16.03^{* * *} \\
(0.000)\end{array}$ \\
\hline
\end{tabular}


End of Table 12

\begin{tabular}{|c|c|c|c|c|}
\hline \multirow{2}{*}{ Variables } & \multirow{2}{*}{ Predicted Sign } & Model (7) & Model (8) & Model (9) \\
\cline { 3 - 5 } & & M\&A_Size & M\&A_Size & M\&A_Size \\
\hline Year & & Yes & Yes & Yes \\
\hline Industry & & Yes & Yes & Yes \\
\hline Adj. $\mathrm{R}^{2}$ & & $7.40 \%$ & $7.69 \%$ & $7.44 \%$ \\
\hline F-statistics & & $6.78^{* * *}$ & $6.99^{* * *}$ & $6.82^{* * *}$ \\
\hline Prob $>$ F & & 0.0000 & 0.0000 & 0.0000 \\
\hline $\mathrm{N}$ & & 1120 & 1120 & 1120 \\
\hline
\end{tabular}

Note: $\mathrm{p}$-values are shown in parentheses; standard deviations are performed Robust process; ${ }^{*},{ }^{*}$ and ${ }^{* * *}$ represent the results are significant at the $10 \%$ level, the $5 \%$ level and the $1 \%$ level, respectively.

We find that the results of Table 12 are consistent with Table 11. Therefore, in terms of the scale of mergers and acquisitions, this paper supports the opinion that IPO over-financing and market value overvaluation are the main drivers of mergers and acquisitions.

\subsection{IPO over-financing, market overvaluation and transaction frequency}

Table 13 examines the impacts of IPO over-financing and market value overvaluation on M\&A in terms of transaction frequency. There's a significant positive relation between IPOOF_Size and M\&A_Freq in model (10) to (15) both in Negative Binomial regression and Poisson regression. The regression coefficients are $0.0899,0.0858,0.0870,0.0885,0.0848$ and 0.0879 , respectively. All the coefficients are significant at the $1 \%$ level. So heavier IPO overfinancing causes more frequent M\&A transactions.

Table 13. IPO over-financing, market overvaluation and transaction frequency

\begin{tabular}{|c|c|c|c|c|c|c|c|}
\hline \multirow{3}{*}{ Variables } & \multirow{3}{*}{$\begin{array}{c}\text { Pre- } \\
\text { dicted } \\
\text { Sign }\end{array}$} & Model (10) & Model (11) & Model (12) & Model (13) & Model (14) & Model (15) \\
\hline & & \multicolumn{3}{|c|}{ Negative Binomial Regression } & \multicolumn{3}{|c|}{ Poisson Regression } \\
\hline & & M\&A_Freq & M\&A_Freq & M\&A_Freq & M\&A_Freq & M\&A_Freq & M\&A_Freq \\
\hline IPOOF_Size & + & $\begin{array}{c}0.0899^{* * *} \\
(0.000)\end{array}$ & $\begin{array}{c}0.0858^{* * *} \\
(0.000)\end{array}$ & $\begin{array}{c}0.0870^{* * *} \\
(0.000)\end{array}$ & $\begin{array}{c}0.0885^{\star * *} \\
(0.000)\end{array}$ & $\begin{array}{c}0.0848^{\star * *} \\
(0.000)\end{array}$ & $\begin{array}{c}0.0879^{* * *} \\
(0.000)\end{array}$ \\
\hline MB_Ave & + & $\begin{array}{c}0.0562^{* * *} \\
(0.000)\end{array}$ & & & $\begin{array}{c}0.0525^{\star * *} \\
(0.000)\end{array}$ & & \\
\hline Ppa_Ave & + & & $\begin{array}{c}0.0378^{\star * *} \\
(0.000)\end{array}$ & & & $\begin{array}{c}0.0386^{* * *} \\
(0.000)\end{array}$ & \\
\hline Tobin's Q_Ave & + & & & $\begin{array}{c}0.0480^{\star * *} \\
(0.000)\end{array}$ & & & $\begin{array}{c}0.0517^{\star * *} \\
(0.000)\end{array}$ \\
\hline Lev_Ave & + & $\begin{array}{c}0.807^{\star * *} \\
(0.001)\end{array}$ & $\begin{array}{c}0.444^{\star} \\
(0.066)\end{array}$ & $\begin{array}{c}0.739^{* * *} \\
(0.002)\end{array}$ & $\begin{array}{c}0.808^{\star * *} \\
(0.000)\end{array}$ & $\begin{array}{c}0.415^{\star} \\
(0.065)\end{array}$ & $\begin{array}{c}0.783^{\star * *} \\
(0.001)\end{array}$ \\
\hline Constant & ? & $\begin{array}{l}-0.375 \\
(0.115)\end{array}$ & $\begin{array}{l}-0.228 \\
(0.340)\end{array}$ & $\begin{array}{l}-0.305 \\
(0.207)\end{array}$ & $\begin{array}{l}-0.340 \\
(0.143)\end{array}$ & $\begin{array}{l}-0.213 \\
(0.353)\end{array}$ & $\begin{array}{l}-0.333 \\
(0.154) \\
\end{array}$ \\
\hline Year & & Yes & Yes & Yes & Yes & Yes & Yes \\
\hline
\end{tabular}


End of Table 13

\begin{tabular}{|c|c|c|c|c|c|c|c|}
\hline \multirow{3}{*}{ Variables } & \multirow{3}{*}{$\begin{array}{l}\text { Pre- } \\
\text { dicted } \\
\text { Sign }\end{array}$} & Model (10) & Model (11) & Model (12) & Model (13) & Model (14) & Model (15) \\
\hline & & \multicolumn{3}{|c|}{ Negative Binomial Regression } & \multicolumn{3}{|c|}{ Poisson Regression } \\
\hline & & M\&A_Freq & M\&A_Freq & M\&A_Freq & M\&A_Freq & M\&A_Freq & M\&A_Freq \\
\hline Industry & & Yes & Yes & Yes & Yes & Yes & Yes \\
\hline Wald chi2 & & $19974.24^{\star * *}$ & $21313.67^{\star * *}$ & $21125.95^{\star \star \star}$ & $10300.26^{* * *}$ & $11195.83^{\star * *}$ & $12461.69^{* * *}$ \\
\hline Prob > chi 2 & & 0.0000 & 0.0000 & 0.0000 & 0.0000 & 0.0000 & 0.0000 \\
\hline $\begin{array}{l}\text { Log pseudo- } \\
\text { likelihood }\end{array}$ & & -3029.5869 & -3034.6462 & -3035.2905 & -3236.362 & -3243.9039 & -3243.5052 \\
\hline Pseudo $\mathrm{R}^{2}$ & & 0.0836 & 0.0820 & 0.0818 & - & - & - \\
\hline $\mathrm{N}$ & & 2632 & 2632 & 2632 & 2632 & 2632 & 2632 \\
\hline
\end{tabular}

Note: p-values are shown in parentheses; standard deviations are performed Robust process; ${ }^{*},{ }^{* *}$ and ${ }^{* * *}$ represent the results are significant at the $10 \%$ level, the $5 \%$ level and the $1 \%$ level, respectively. We use company stock code clustering in the Negative Binomial and Poisson regression model.

Besides, there's a significant positive relation between MB_Ave, Ppa_Ave, Tobin's Q_Ave and M\&A_Freq. The regression coefficients are 0.0562, 0.0378, 0.0480, 0.0525, 0.0386 and 0.0517 , respectively. The coefficients are significant at the $1 \%$ level. This shows that companies will make use of overvalued stock to acquire other companies under market value overvaluation. Also, greater overvaluation brings about more frequent M\&A transactions.

In summary, our empirical results and analysis show that IPO over-financing and market value overvaluation are the main drivers of mergers and acquisitions in terms of transaction frequency. Hypothesis 1 and hypothesis 2 are thus validated.

\subsection{Market reaction to different method of payment}

Table 14 reports on the market reaction to different payment methods. As we can see from the data in Panel A, all values of CAR of cash payments, stock payments and cash-and-stock mixed payment, both mean and median values, are significantly positive and significant at the $1 \%$ level. This shows a positive reaction of markets to M\&A in the ChiNext market. M\&A seems to have a wealth effect. This is different from the empirical evidence from the United States and Europe. It's worth noticing that all values of CAR, both mean or median values in all groups, are above zero on average in cash payment group, stock payment group and cash-and-stock mixed payment group. The results are consistent with the research of Fuller et al. (2002) and Moeller et al. (2004). Market reactions to cash payments, stock payments and cash and stock mixed payments are significantly positive when the acquirees are nonlisted companies.

The differences in market reactions to various payment methods are significant, as demonstrated by data shown in Panel B. On average all values of CAR of cash payment group are significantly lower than those of stock payment group and cash-and-stock mixed payment group. The differences are significant at the $1 \%$ level, in both mean and median values. It's indicated that market reactions to stock payments and cash-and-stock mixed payments are stronger than that to cash payments. Stock payments and cash and stock mixed payments 


\begin{tabular}{|c|c|c|c|c|c|c|c|c|c|c|c|c|c|}
\hline in & 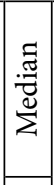 & & 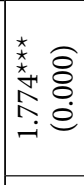 & 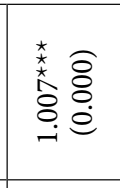 & 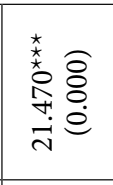 & 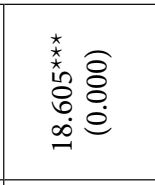 & 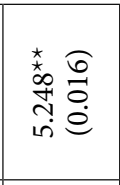 & 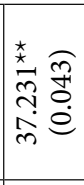 & & 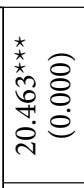 & 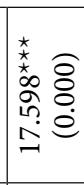 & $\begin{array}{l}\widehat{0} \\
0 \\
\infty \\
0 \\
0 \\
0 \\
\infty \\
i \\
i\end{array}$ & 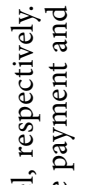 \\
\hline$\approx$ & $\stackrel{\Xi}{\Sigma}^{\Xi}$ & & 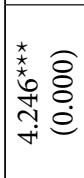 & 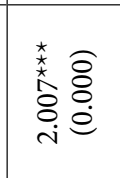 & 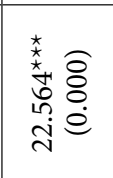 & 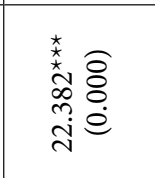 & 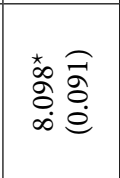 & $\begin{array}{ll}x & \widehat{x} \\
\hat{L} & \infty \\
\infty & 0 \\
0 & 0 \\
\grave{2} & 0\end{array}$ & & 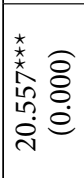 & 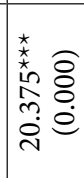 & 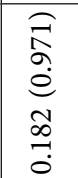 & 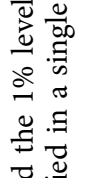 \\
\hline $\begin{array}{l}f \\
f\end{array}$ & 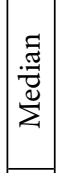 & & 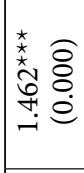 & 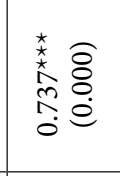 & 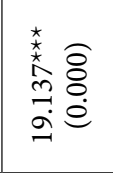 & 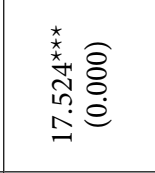 & 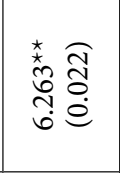 & 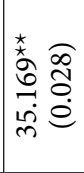 & & 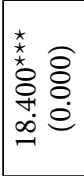 & 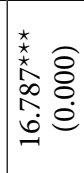 & $\begin{array}{l}\widehat{\infty} \\
\infty \\
\infty \\
0 \\
0 \\
m \\
0 \\
0 \\
-i\end{array}$ & 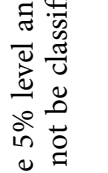 \\
\hline 承 & $\stackrel{\Xi}{\Sigma}^{\Xi}$ & \begin{tabular}{l}
0 \\
$\tilde{z}$ \\
0 \\
\multirow{2}{*}{} \\
\end{tabular} & 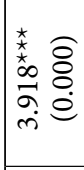 & 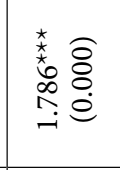 & 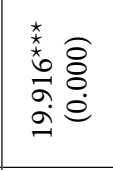 & 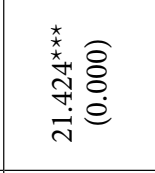 & 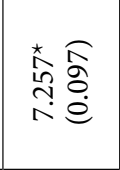 & 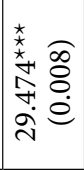 & $\frac{\infty}{0}$ & 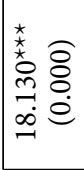 & 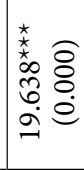 & 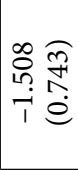 & 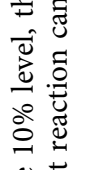 \\
\hline m & 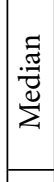 & 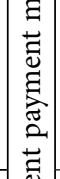 & 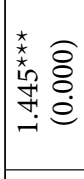 & 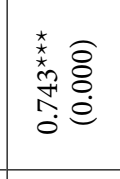 & 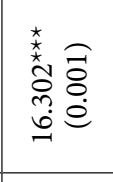 & 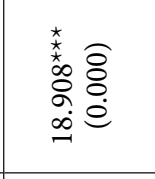 & 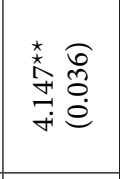 & 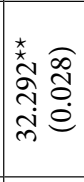 & 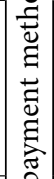 & 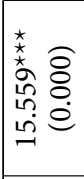 & 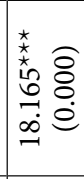 & 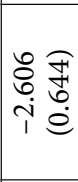 & 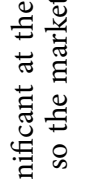 \\
\hline 死 & 苋 & 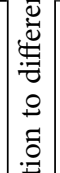 & 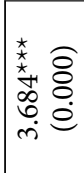 & 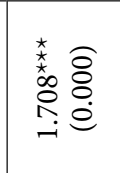 & 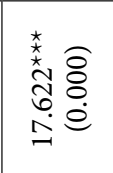 & 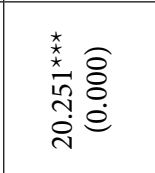 & 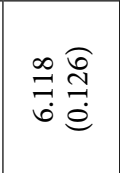 & 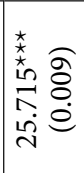 & 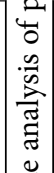 & 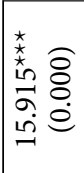 & 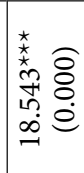 & $\begin{array}{ll}\stackrel{\infty}{\hat{\sigma}} & \infty \\
i & n \\
i & 0\end{array}$ & 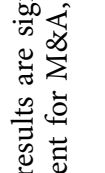 \\
\hline $\begin{array}{l}\text { N } \\
\text { i } \\
\text { I }\end{array}$ & 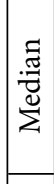 & 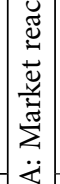 & 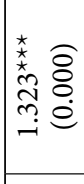 & 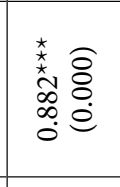 & 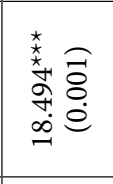 & 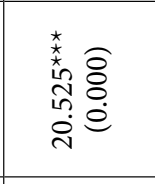 & 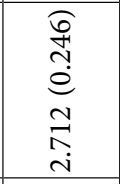 & 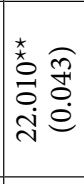 & 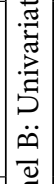 & 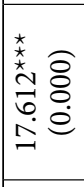 & 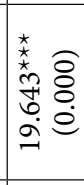 & $\begin{array}{ll}\vec{r} & \widehat{n} \\
0 & \hat{n} \\
i & 0 \\
1 & e\end{array}$ & 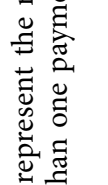 \\
\hline$\frac{2}{4}$ & $\stackrel{\Xi}{\Xi}$ & 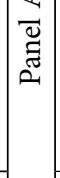 & 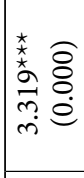 & 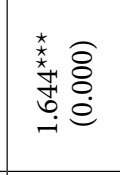 & 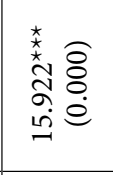 & 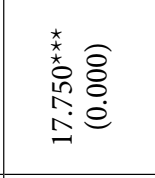 & 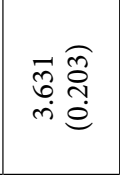 & 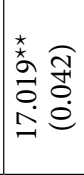 & $\tilde{\Xi}$ & 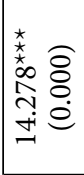 & 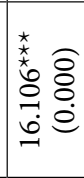 & 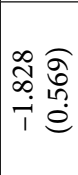 & 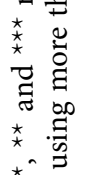 \\
\hline I & 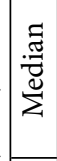 & & 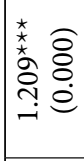 & 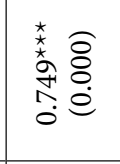 & 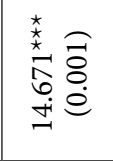 & 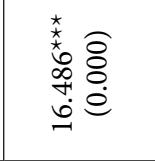 & 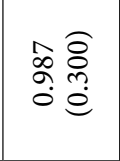 & 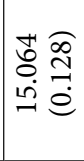 & & 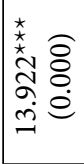 & 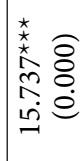 & $\begin{array}{ll}n & 0 \\
\infty & \infty \\
0 & 0 \\
\rightarrow & 0 \\
1 & 0\end{array}$ & 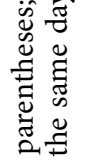 \\
\hline 胥 & $\sum_{\Sigma}^{\mathbb{\Xi}}$ & & 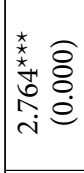 & 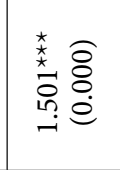 & 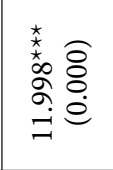 & 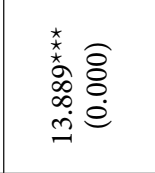 & 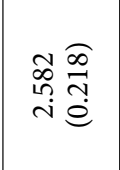 & $\begin{array}{ll}0 & \widehat{c} \\
\infty & 0 \\
0 & 0 \\
0 & 0 \\
= & 0\end{array}$ & & 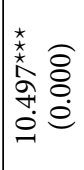 & 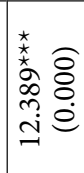 & 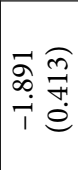 & 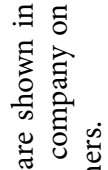 \\
\hline & ex & & 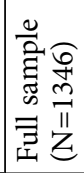 & 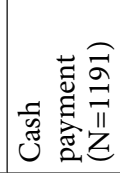 & 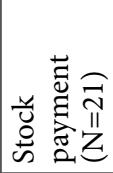 & 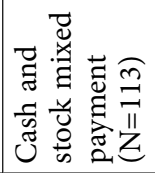 & 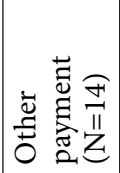 & 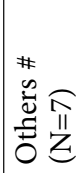 & & 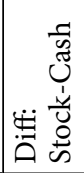 & 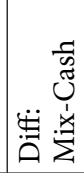 & 离 & 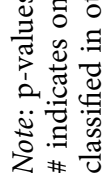 \\
\hline
\end{tabular}


seem to be with stronger wealth effects. So making use of overvalued stock for M\&A conveys positive signals to the market under the condition that market value overvaluation is prevalent among ChiNext companies. Last but not least, differences between Stock payment group and Cash-and-stock mixed payment group aren't significant on average, in either mean or median values. Hypothesis 3 is thus validated.

\subsection{Market reaction to $M \& A$ sequences}

The ChiNext market has seen acquisition sequences nowadays. 104 and 178 companies have been involved in more than two M\&A transactions in the year of 2014 and 2015 respectively. Companies such as Aier Eye Hospital, Huayi Brothers, Walvax Biotechnology, Xiangxue Pharmaceutical Co., Ltd., Landocean Energy Services, Ultrapower Software and Jetsen Technology have conducted more than 10 times of M\&A in the year from 2009 to 2016. Therefore, transaction frequency needs to be considered when we talk about market reaction. We further calculated CAR under different times of M\&A, as summarized in Table 15.

It's shown in Table 15 that all values of CAR tend to decrease as the frequency of M\&A increase, in both mean and median values. This means the increase in freuency of M\&A weakens the wealth effect. This finding agrees with the conclusions of Fuller et al. (2002) and Aktas et al. (2013). More frequent M\&As lead to weaker positive market reaction. At present, the ChiNext companies are busy digesting IPO over-financing funds and conducting frequent M\&As. They hardly have time learning from and reflecting on the M\&A, accumulating related experience and capturing important market information. The gradually weakening positive responses of market suggest the investors' negative judgement towards M\&A sequences.

Table 15. Market reaction to M\&A sequences

\begin{tabular}{|c|c|c|c|c|c|c|c|c|c|c|}
\hline \multirow{2}{*}{ CAR $(\%)$} & \multicolumn{2}{|c|}{$\operatorname{CAR}(-1,1)$} & \multicolumn{2}{|c|}{$\operatorname{CAR}(-2,2)$} & \multicolumn{2}{|c|}{$\operatorname{CAR}(-3,3)$} & \multicolumn{2}{|c|}{$\operatorname{CAR}(-4,4)$} & \multicolumn{2}{|c|}{$\operatorname{CAR}(-5,5)$} \\
\hline & Mean & Median & Mean & Median & Mean & Median & Mean & Median & Mean & Median \\
\hline \multicolumn{11}{|c|}{ Panel A: Market reaction to different times of M\&A } \\
\hline $\begin{array}{l}\text { Full } \\
\text { sample } \\
(\mathrm{N}=1346)\end{array}$ & $\begin{array}{c}2.764^{\star * *} \\
(0.000)\end{array}$ & $\begin{array}{c}1.209^{\star * *} \\
(0.000)\end{array}$ & $\begin{array}{c}3.319^{\star * *} \\
(0.000)\end{array}$ & $\begin{array}{c}1.323^{* * *} \\
(0.000)\end{array}$ & $\begin{array}{c}3.684^{\star * *} \\
(0.000)\end{array}$ & $\begin{array}{l}1.445^{\star * *} \\
(0.000)\end{array}$ & $\begin{array}{c}3.918^{\star * *} \\
(0.000)\end{array}$ & $\begin{array}{l}1.462^{* * *} \\
(0.000)\end{array}$ & $\begin{array}{c}4.246^{\star * *} \\
(0.000)\end{array}$ & $\begin{array}{c}1.774^{\star * *} \\
(0.000)\end{array}$ \\
\hline $\begin{array}{l}\text { 1st and } \\
2 \mathrm{nd} \\
(\mathrm{N}=557)\end{array}$ & $\begin{array}{c}3.574^{\star * *} \\
(0.000)\end{array}$ & $\begin{array}{c}1.566^{\star * *} \\
(0.000)\end{array}$ & $\begin{array}{c}4.395^{\star * *} \\
(0.000)\end{array}$ & $\begin{array}{c}1.925^{\star * *} \\
(0.000)\end{array}$ & $\begin{array}{c}4.879^{* * *} \\
(0.000)\end{array}$ & $\begin{array}{c}2.275^{\star * *} \\
(0.000)\end{array}$ & $\begin{array}{c}4.929^{* * *} \\
(0.000)\end{array}$ & $\begin{array}{c}2.442^{\star * *} \\
(0.000)\end{array}$ & $\begin{array}{c}5.161^{\star * *} \\
(0.000)\end{array}$ & $\begin{array}{c}2.523^{\star * *} \\
(0.000)\end{array}$ \\
\hline $\begin{array}{l}3 \mathrm{rd}, 4 \text { th } \\
\text { and } 5 \text { th } \\
(\mathrm{N}=455)\end{array}$ & $\begin{array}{c}2.750^{* * *} \\
(0.000)\end{array}$ & $\begin{array}{c}1.201^{\star * *} \\
(0.000)\end{array}$ & $\begin{array}{c}3.142^{\star * *} \\
(0.000)\end{array}$ & $\begin{array}{c}1.439^{* * *} \\
(0.000)\end{array}$ & $\begin{array}{c}3.272^{\star * *} \\
(0.000)\end{array}$ & $\begin{array}{c}1.314^{* * *} \\
(0.000)\end{array}$ & $\begin{array}{c}3.462^{\star * *} \\
(0.000)\end{array}$ & $\begin{array}{l}1.204^{\star * *} \\
(0.000)\end{array}$ & $\begin{array}{c}3.721^{\star * *} \\
(0.000)\end{array}$ & $\begin{array}{c}1.309^{\star * *} \\
(0.000)\end{array}$ \\
\hline $\begin{array}{l}\geq 6 \text { th } \\
(\mathrm{N}=334)\end{array}$ & $\begin{array}{c}1.434^{* * *} \\
(0.000)\end{array}$ & $\begin{array}{c}0.384^{* * *} \\
(0.004)\end{array}$ & $\begin{array}{c}1.767^{\star * *} \\
(0.000)\end{array}$ & $\begin{array}{l}0.435^{\star *} \\
(0.011)\end{array}$ & $\begin{array}{c}2.251^{\star * *} \\
(0.000)\end{array}$ & $\begin{array}{c}0.580^{* * *} \\
(0.005)\end{array}$ & $\begin{array}{c}2.854^{* * *} \\
(0.000)\end{array}$ & $\begin{array}{c}0.881^{\star * *} \\
(0.001)\end{array}$ & $\begin{array}{c}3.435^{\star * *} \\
(0.000)\end{array}$ & $\begin{array}{c}1.545^{\star * *} \\
(0.000)\end{array}$ \\
\hline \multicolumn{11}{|c|}{ Panel B: Univariate analysis of M\&A sequences } \\
\hline $\begin{array}{l}\text { Diff: } \\
\text { 1st and } \\
\text { 2nd - 6th } \\
\text { times and } \\
\text { more }\end{array}$ & $\begin{array}{c}2.140^{\star * *} \\
(0.000)\end{array}$ & $\begin{array}{c}1.182^{\star * *} \\
(0.001)\end{array}$ & $\begin{array}{c}2.628^{\star * *} \\
(0.000)\end{array}$ & $\begin{array}{c}1.490^{\star * *} \\
(0.000)\end{array}$ & $\begin{array}{c}2.628^{* * *} \\
(0.001)\end{array}$ & $\begin{array}{l}1.695^{\star * *} \\
(0.001)\end{array}$ & $\begin{array}{l}2.075^{\star *} \\
(0.022)\end{array}$ & $\begin{array}{l}1.561^{\star *} \\
(0.023)\end{array}$ & $\begin{array}{c}1.726^{\star} \\
(0.077)\end{array}$ & $\begin{array}{c}0.978^{*} \\
(0.097)\end{array}$ \\
\hline
\end{tabular}

Note: p-values are shown in parentheses; ${ }^{*},{ }^{* *}$ and ${ }^{* *}$ represent the results are significant at the $10 \%$ level, the $5 \%$ level and the $1 \%$ level, respectively. 


\section{Conclusions and discussions}

There has been a wave of M\&A in the ChiNext market over the past years. Based on the neoclassical theory, the behavioral theory and China's reality, this paper explains the M\&A upsurge of the ChiNext market from the perspectives of IPO over-financing and the market value overvaluation. The main findings are stated as follows.

Firstly, IPO over-financing that is characteristic of the Chinese capital market is one of the driving forces for enterprises' M\&A, bringing far-reaching impacts on such aspects as acquisition probability, the size of the transaction, transaction frequency, M\&A payment method and market reaction. Due to IPO over-financing, enterprises tend to carry out M\&A via cash payment or cash and stock mixed payment method. Heavier IPO over-financing will increase the chance of M\&A and leads to larger transaction size and higher transaction frequency.

Secondly, market value overvaluation is also a driving force for enterprises' M\&A. Market value overvaluation leads to more uses of stock or cash-and-stock mixed payment in M\&A transactions. When the company's stock is overvalued, the company will use the overvalued equity to acquire other companies. Greater overvaluation of the market value also increases the chance of M\&A, and leads to a larger transaction size and higher frequency of M\&A. However, compared to market value overvaluation, IPO financing is the major driving factor for China's M\&A.

Thirdly, all acquirees of M\&A in the ChiNext market are non-listed companies. The market reaction to different payment methods in M\&A varies: it has a minimum reaction on cash payment, a larger reaction on stock payment and the largest reaction on mixed payment. Also, the mixed payment method has the largest cumulative abnormal returns. In addition, sequent M\&As will weaken the wealth effect. The increasing number of M\&As lead to weaker positive responses of the market.

The ChiNext market is an important constituent of the multi-level capital market in China. It has been shouldering the duty of accelerating the transformation of the path of economic development. In addition, it has also carried the responsibility for cultivating and developing strategic emerging industries, as well as implementing the national independent innovation strategy. The fundamental role of capital markets is to optimize the resource allocation, where M\&A is one of the ways to fulfill this role. This paper provides a theoretical basis and empirical evidence for enhancing the efficiency of market resources allocation through study of the wave of M\&A. Firstly, IPO over-financing reflects the excessive capital liquidity and is the essential driver for the wave of M\&A. IPO over-financing results in resource mismatches, severe agency conflicts and low capital utilization efficiency, which are harmful to the long-term stability and healthy development of the ChiNext market. Therefore, regulatory authorities should control and manage excessive capital liquidity at its root, actively broaden the channels of social investment as well as financing and provide guidance on the rational allocation of social resources so that IPO over-financing will be minimized.

Secondly, considering the rigid regulatory power of CSRC and the Shenzhen Stock Exchange on the use of IPO over-financing funds, M\&A is a sensible application of giant IPO over-financing funds in the ChiNext market. To this end, governmental departments must strengthen the regulation of M\&A in the ChiNext market, especially the regulation of serial M\&A and supervision of M\&A performance. Negative impacts of unnecessary M\&A should be prevented and the efficiency of the use of IPO over-financing funds should be enhanced. 
Thirdly, proper concepts of market value management shall be established in ChiNext companies that under market value overvaluation. Stock price going up too rapidly could cause grave damage. Overvalued stock should be taken advantage of through the purchase of other companies' physical assets at selective timing, especially when it comes to the purchases of critical technology assets and innovation resources. In this way they can achieve effective market value management and high-quality expansion.

Last but not least, the vast medium and small investors should reasonably judge the driving factors of M\&A in ChiNext companies and pay attention to the payment methods and M\&A performance. Acts of deception, where companies with weak endogenous development make unfaithful profits, and perform earnings management through M\&A, always call for vigilance.

\section{Acknowledgements}

This study is supported by the National Natural Science Foundation of China (Project No. 71402189) and the Fundamental Research Funds for the Central Universities of the Chinese Ministry of Education (Project No. 2014116). This study is also supported by the Fundamental Research Funds for the Central Universities of the Chinese Ministry of Education (Project Title is "Financial Management Frontier Issues Research Team of Accounting School of Zhongnan University of Economics and Law").

\section{References}

Aktas, N., Bodt, E. D., \& Roll, R. (2013). Learning from repetitive acquisitions: evidence from the time between deals. Journal of Financial Economics, 108(1), 99-117.

https://doi.org/10.1016/j.jineco.2012.10.010

Andrade, G., Mitchell, M., \& Stafford, E. (2001). New evidence and perspectives on mergers. Journal of Economic Perspectives, 15, 103-120. https://doi.org/10.1257/jep.15.2.103

Ang, J., \& Cheng, Y. M. (2006). Direct evidence on the market-driven acquisition. Journal of Financial Research, 29, 199-216. https://doi.org/10.1111/j.1475-6803.2006.00174.x

Arikan, A. M., \& Stulz, R. M. (2016). Corporate acquisitions, diversification, and the firm's life cycle. Journal of Finance, 71(1), 139-193. https://doi.org/10.1111/jofi.12362

Baker, M., Stein, J. C., \& Wurgler, J. (2003). When does the market matter? Stock prices and the investment of equity-dependent firms. Quarterly Journal of Economics, 118, 969-1005. https://doi.org/10.1162/00335530360698478

Bekkum, S. V., Han, S., \& Pennings, E. (2011). Buy smart, time smart: are takeovers driven by growth opportunities or mispricing?. Financial Management, Winter, 911-940. https://doi.org/10.1111/j.1755-053X.2011.01166.x

Betton, S., Eckbo, B. E., \& Thorburn, K. (2008). Corporate takeovers. In B. E. Eckbo (Ed.), Handbook of corporate finance: empirical corporate finance, vol. 2. Elsevier/North-Holland.

Chang, S. (1998). Takeovers of privately held targets, methods of payment, and bidder returns. Journal of Finance, 53(2), 773-784. https://doi.org/10.1111/0022-1082.315138

China Securities Regulatory Commission. (2009). Guiding opinions on further reforming and improving the issuance system of new shares. Retrieved from http://www.csrc.gov.cn/pub/newsite/flb/flfg/ bmgf/fx/fxycx/201012/t20101231_189641.html 
China Securities Regulatory Commission. (2009). Interim measures on administration of initial public offering and listing on the ChiNext. Retrieved from http://www.csrc.gov.cn/pub/newsite/zjhxwfb/ xwdd/200903/t20090331_99727.html

China Securities Regulatory Commission. (2010). Guiding opinions on deepening the reforms in the issuance system of new shares. Retrieved from http://www.csrc.gov.cn/pub/newsite/flb/flfg/bmgf/ fx/fxycx/201012/t20101231_189628.html

China Securities Regulatory Commission. (2014). Measures on administration of initial public offering and listing on the ChiNext. Retrieved from http://www.csrc.gov.cn/pub/newsite/flb/flfg/bmgz/ fxl/201805/t20180515_338130.html

Datta, S., Iskandar-Datta, M., \& Raman, K. (2001). Executive compensation and corporate acquisition decisions. Journal of Finance, 56(6), 2299-2336. https://doi.org/10.1111/0022-1082.00406

Dong, M., Hirshleifer, D., Richardson, S., \& Hong Teoh, S. (2006). Does investor misvaluation drive the takeover market?. Journal of Finance, 61(2), 725-762. https://doi.org/10.1111/j.1540-6261.2006.00853.x

Eckbo, B. E. (2009). Bidding strategies and takeover premiums: a review. Journal of Corporate Finance, 15, 149-178. https://doi.org/10.1016/j.jcorpfin.2008.09.016

Eckbo, B. E., \& Thorburn, K. S. (2000). Gains to bidder firms revisited: domestic and foreign acquisitions in Canada. Journal of Financial and Quantitative Analysis, 35(1), 1-25. https://doi.org/10.2307/2676236

Faccio, M., \& Masulis, R. W. (2005). The choice of payment method in European mergers and acquisitions, Journal of Finance, 60(3), 1345-1388. https://doi.org/10.1111/j.1540-6261.2005.00764.x

Fang, J. X., \& Fang, F. (2011). Over-funding in IPO and capital misuse in China's market. Securities Market Herald, 9, 37-42 (in Chinese).

Fuller, K., Netter, J., \& Stegemoller, M. (2002). What do returns to acquiring firms tell us? Evidence from firms that make many acquisitions. Journal of Finance, 57(4), 1763-1793. https://doi.org/10.1111/1540-6261.00477

Harford, J. (1999). Corporate cash reserves and acquisitions. Journal of Finance, 54(6), 1969-1997. https://doi.org/10.1111/0022-1082.00179

Harford, J. (2005). What drives merger waves?. Journal of Financial Economics, 77, 529-560. https://doi.org/10.1016/j.jfineco.2004.05.004

Holmstrom, B., \& Kaplan, S. N. (2001). Corporate governance and merger activity in the US: making sense of the 1980s and 1990s. Journal of Economic Perspectives, 15, 121-144. https://doi.org/10.1257/jep.15.2.121

$\mathrm{Hu}$, M., \& Yang, J. J. (2016). The role of leverage in cross-border mergers and acquisitions. International Review of Economics and Finance, 43, 170-199. https://doi.org/10.1016/j.iref.2015.10.039

Jensen, M. C. (1986). Agency costs of free cash flow, corporate finance, and takeovers. American Economic Review 76(2), 323-29.

Jensen, M. C. (2005). Agency costs of overvalued equity. Financial Management, 34(1), 5-19. https://doi.org/10.1111/j.1755-053X.2005.tb00090.x

Jovanovic, B., \& Rousseau, P. (2002). The Q-theory of mergers. American Economic Review, 92(2), 198204. https://doi.org/10.1257/000282802320189249

Lang, L., Stulz, R., \& Walking, R. (1991). A test of the free cash flow hypothesis: the case of bidder return. Journal of Financial Economics, 29(2), 315-335. https://doi.org/10.1016/0304-405X(91)90005-5

Liu, F. (2017). The significance of research. China Journal of Accounting Research, 10(3), 227-230.

Maksimovic, V., \& Phillips, G. (2001). The market for corporate assets: who engage in mergers and asset sales and are there efficiency gains?. Journal of Finance, 56, 2019-2065.

https://doi.org/10.1111/0022-1082.00398 
Maksimovic, V., Phillips, G., \& Yang, L. (2013). Private and public mergers waves. Journal of Finance, 68(5), 2177-2217. https://doi.org/10.1111/jofi.12055

Martynova, M., \& Renneboog, L. (2009). What determines the financing decision in corporate takeovers: cost of capital, agency problems, or the means of payment?. Journal of Corporate Finance, 15, 290-315. https://doi.org/10.1016/j.jcorpfin.2008.12.004

Mitchell, M. L., \& Mulherin, J. H. (1996). The impact of industry shocks on takeovers and restructuring activity. Journal of Financial Economics, 41, 193-229. https://doi.org/10.1016/0304-405X(95)00860-H

Moeller, S. B., Schlingemann, F. P., \& Stulz, R. M. (2004). Firm size and the gains from acquisitions. Journal of Financial Economics, 73, 201-228. https://doi.org/10.1016/j.jfineco.2003.07.002

Moeller, S. B., Schlingemann, F. P., \& Stulz, R. M. (2005). Wealth destruction on a massive scale? A study of acquiring-firm returns in the resent merger wave. Journal of Finance, 60(2), 757-782. https://doi.org/10.1111/j.1540-6261.2005.00745.x

Officer, M. S. (2007). The price of corporate liquidity: acquisition discount for unlisted targets. Journal of Financial Economics, 83(3), 571-598. https://doi.org/10.1016/j.jfineco.2006.01.004

Rhodes-Kropf, M., \& Viswanathan, S. (2004). Market valuation and merger waves. Journal of Finance, 59(6), 2685-2718. https://doi.org/10.1111/j.1540-6261.2004.00713.x

Rhodes-Kropf, M., Viswanathan, S., \& Robinson, D. T. (2005). Valuation waves and merger waves: the empirical evidence. Journal of Financial Economics, 77(3), 561-603. https://doi.org/10.1016/j.jfineco.2004.06.015

Savor, P. G., \& Lu, Q. (2009). Do stock mergers create value for acquirers. Journal of Finance, 64(3), 1061-1097. https://doi.org/10.1111/j.1540-6261.2009.01459.x

Servaes, H. (1991). Tobin's Q and the gains from takeovers. Journal of Finance, 46(1), 409-419. https://doi.org/10.1111/j.1540-6261.1991.tb03758.x

Shenzhen Stock Exchange. (2012). Memorandum No.1 on Information Disclosure by ChiNext Companies - IPO Over-financing. Retrieved from http://www.szse.cn/main/rule/bsywgz/ssgsl/cybzy_ front/

Shleifer, A., \& Vishny, R. W. (1992). Liquidation values and debt capacity. Journal of Finance, 32, 337347.

Shleifer, A., \& Vishny, R. W. (2003). Stock market driven acquisitions. Journal of Financial Economics, 70(3), 295-311. https://doi.org/10.1016/S0304-405X(03)00211-3

Song, S. L., Tan, J. S., \& Yi, Y. (2014). IPO initial returns in China: underpricing or overvaluation?. China Journal of Accounting Research, 7(1), 31-49. https://doi.org/10.1016/j.cjar.2013.12.001

State Administration of Taxation of The People's Republic of China. (2009). Circular on some policy questions concerning the handling of income taxes in the restructuring of enterprises. Retrieved from http://www.chinatax.gov.cn//n810341/n810765/n812166/n812637/c1188923/content.html

Tao, Q. Z., Sun, W. J., Zhu, Y. J., \& Zhang, T. (2017). Do firms have leverage targets? New evidence from mergers and acquisitions in China. North American Journal of Economics and Finance, 40, 41-54. https://doi.org/10.1016/j.najef.2017.01.004

Tebourbi, I. (2012). Timing of mergers and acquisitions: evidence from the Canadian stock market. International Journal of Economics and Finance, 4(9), 87-107. https://doi.org/10.5539/ijef.v4n9p87

Xu, E. Q. Y. (2017). Cross-border merger waves. Journal of Corporate Finance, 46(5), 207-231. https://doi.org/10.1016/j.jcorpfin.2017.07.004

Xu, X., \& Xia, Y. (2012). Internal corporate governance and the use of IPO over-financing: evidence from China. China Journal of Accounting Research, 5(3), 231-249.

https://doi.org/10.1016/j.cjar.2012.08.003 